\title{
K JOHANITSKÉ KURII V RADOMYŠLI U STRAKONIC
}

\author{
BOŘIVOJ NECHVÁTAL
}

\begin{abstract}
Abstrakt: Při archeologickém výzkumu raně středověkého mladohradištního pohřebiště, který prováděl v letech 1963-1968 Archeologický ústav ČSAV nejdřive jako záchranný a později systematický, byla kromé 1000 až 1200 pohřbených zjištěna řada středověkých objekti̊. Vedle výzkumu románského kostela sv. Martina z poloviny 12. století byla také odkryta johanitská kurie v plášti barokního špýchárku a rozsáhlý komplex sklepů (Nechvátal 1999; 2008). V letech 2015-2016 byla provedena generální oprava a stavebni zabezpečeni johanitské kurie. Stavebni prüzkum stavby provádèli pracovníci Národního památkového ústavu, územního odborného pracoviště v Českých Budějovicích (Jiři Hloch, Jan Eliška, Lenka Vejvodová). Archeologický výzkum probihal pod vedením Vlastimila Krále z Muzea středního Pootaví ve Strakonicich. Revize staré dokumentace a jeji kritické posouzeni, včetně nových zjištění, vedly k upresněni dosavadního poznání. Analýza archeologických a písemných pramenů umožnila zjistit pèt vývojových etap johanitské kurie v Radomyšli.
\end{abstract}

Klíčová slova: johanitská kurie - archeologický a stavební výzkum.

\section{The Order of St. John curia in Radomyšl, near Strakonice}

Abstract: Archaeological research into an early medieval, Late Hillfort period burial site conducted in 1963-1968 by the Archaeological Institute of the Czechoslovak Academy of Sciences, first as rescue research and later as systematic, yielded, along with some 1,000-1,200 burials, also a number of medieval features. Apart from research into the Romanesque Church of St. Martin from the mid-12th century, a curia of the Order of St. John was unearthed within a baroque granary, as well as an extensive network of cellars (Nechvátal 1999; 2008). The general restoration and the building securing of the Order of St. John curia were carried out in 2015-2016. Building research into the construction was conducted by the National Heritage Institute in České Budějovice (Jiři Hloch, Jan Eliška, Lenka Vejvodová). Archaeological research was done under the guidance of Vlastimil Král from the Museum of the Central Otava Region in Strakonice. A review of old documentation and its critical assessment, including new findings, led to the specification of the existing knowledge. The analysis of archaeological and written sources enabled the identification of five development stages of the Order of St. John curia in Radomyšl.

Key words: Order of St. John curia - archaeological and building research.

\section{I.}

Při archeologickém výzkumu raně středověkého mladohradištního pohřebiště, který prováděl v letech 1963-1968 Archeologický ústav ČSAV, nejdříve jako záchranný a později systematický, byla kromě 1000 až 1200 pohřbených zjištěna řada středověkých objektů. Mimo výzkumu románského kostela sv. Martina z poloviny 12. století byla také odkryta johanitská kurie v plášti barokního špýchárku a rozsáhlý komplex sklepů (Nechvátal 1999; 2008). V letech 2015-2016 byla provedena generální oprava a stavební zabezpečení johanitské kurie. Stavební výzkum a zabezpečení stavby realizovali pracovníci Národního památkového ústavu, územního odborného pracoviště v Českých Budějovicích (Jiří Bloch, Jan Eliška, Lenka Vejvodová). Archeologický výzkum vedl Vlastimil Král z Muzea středního Pootaví ve Strakonicích. Revize staré dokumentace a její kritické posouzení, včetně nových zjištění, vedly k upřesnění dosavadního poznání. Stavební práce byly prováděny podle projektu BK design inženýrská projektová kancelář. Dokumentace, která byla přiložena k projektu, nemá ani jeden půdorysný pán a také okrové rámování na východní a jižní straně není úplné. Rovněž chybí některé stavební detaily stávajícího stavu. Bylo nutno vše doplnit.

II.

První majetky johanitského řádu v jižních Čechách se objevují již v osmdesátých letech 12. století, např́klad Markel (Pomezí), který byl společně s Mnichem majetkem johanitské 


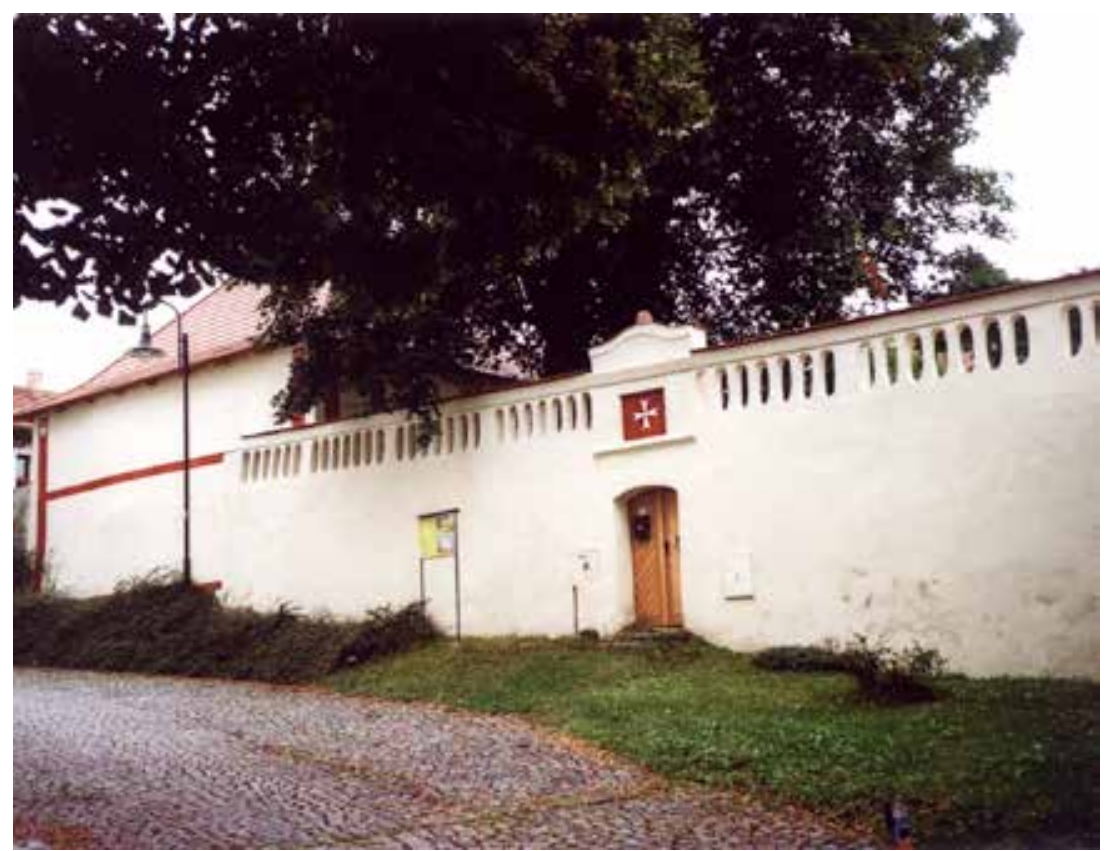

Obr. 1. Pohled od západu na areál johanitské kurie v Radomyšli. Na levé straně budova kurie v barokním plášti, stav v roce 2016. Foto $B$. Nechvátal.

Abb. 1. Blick von Westen auf das Areal der johannitischen Kurie in Radomyšl. Auf der linken Seite das Gebäude der Kurie in barocker Hülle, Zustand im Jahr 2016. Foto B. Nechvátal.

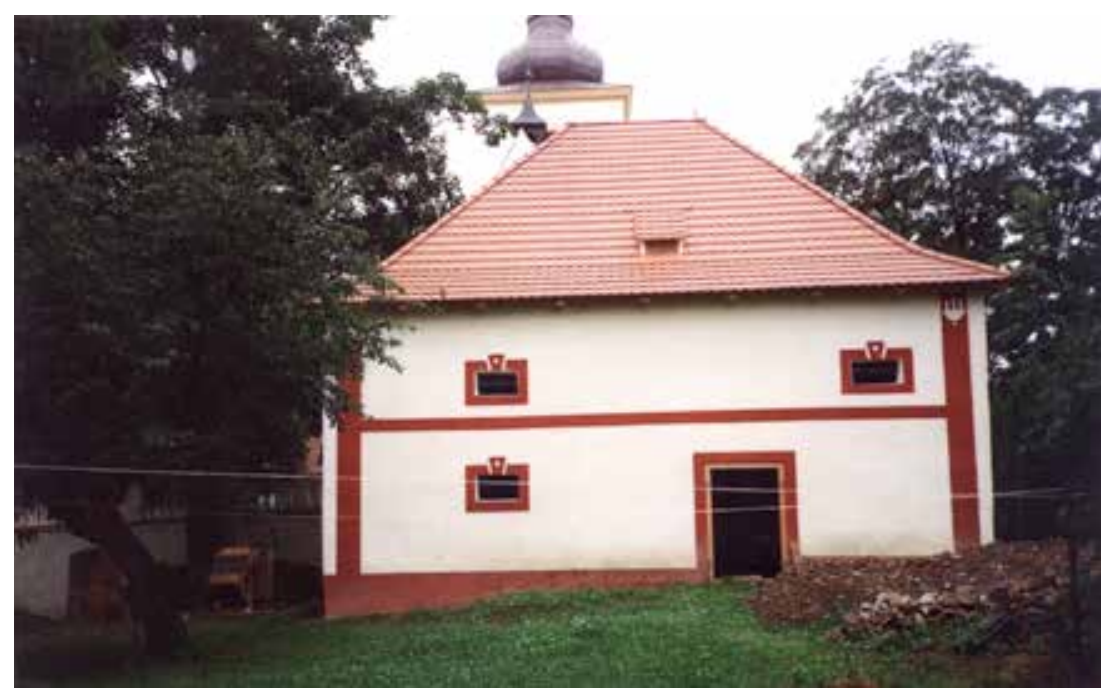

Obr. 2. Pohled od východu na průčelí johanitské kurie, stav v roce 2016. Foto B. Nechvátal.

Abb. 2. Blick von Osten auf die Fassade der johannitischen Kurie, Zustand im Jahr 2016. Foto B. Nechvátal. 


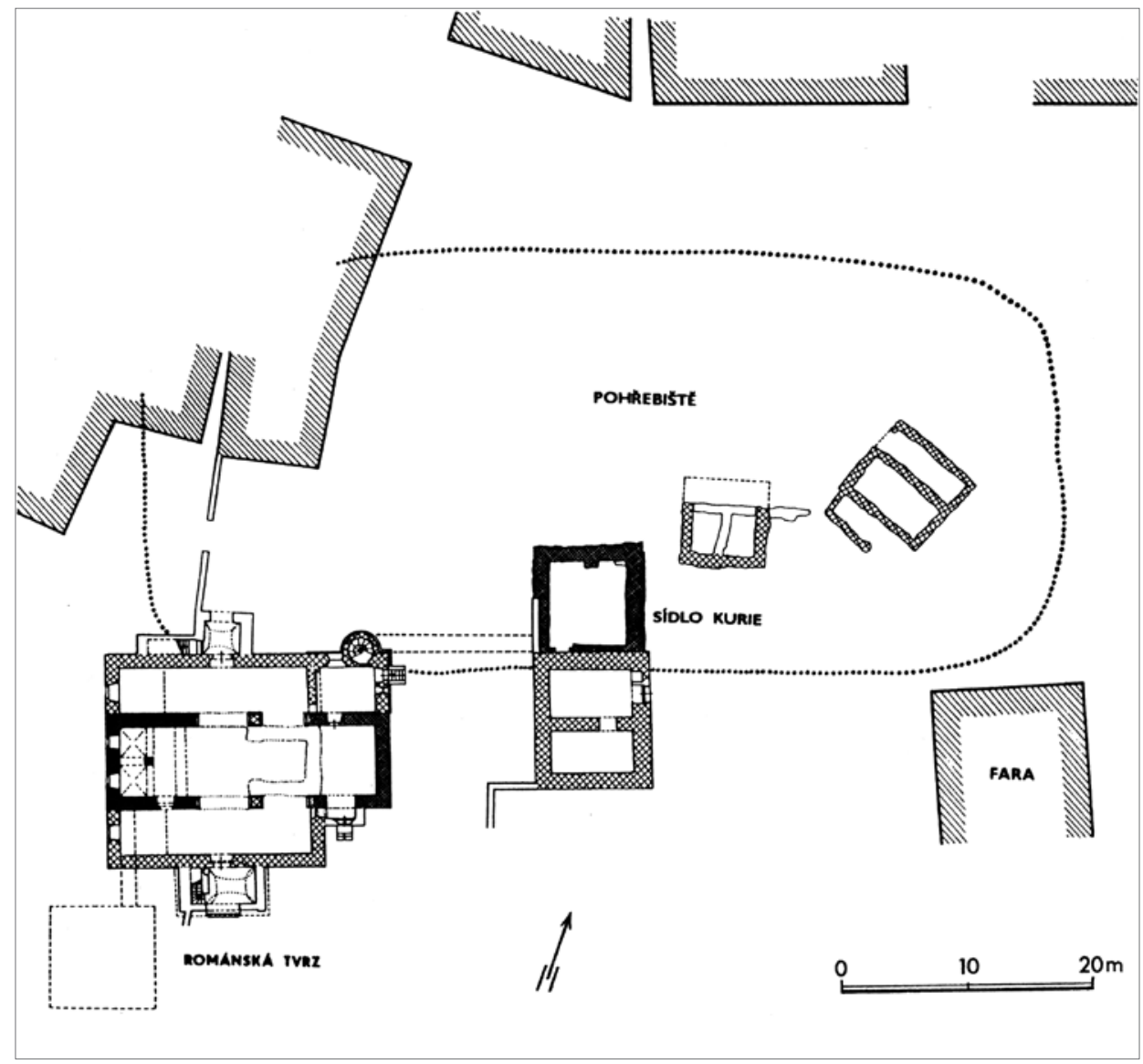

Obr. 3. Celková situace raně středověkého pohřebiště, kostela a sídlištních objektů.

Abb. 3. Gesamtsituation des frühmittelalterlichen Gräberfeldes, der Kirche und Siedlungsobjekte.

komendy v Mailberce, která již roku 1175 vlastnila některé pozemky v jižních Čechách (Sedláček 1908; Šimák 1938; Profous 1957). Stejně jako některé oblasti západních Čech - Manětínsko. Počátky johanitů v českých zemích jsou z období po druhé kř́ižové výpravě. Byli k nám přivedeni za Vladislava II. (1140-1173) vyšehradským proboštem a královským kancléřem Gervasiem a jeho notářem Martinem (mezi léty 1165-1169). Ze svého pražského střediska (kostel Panny Marie, konec mostu na Malé Straně) se velmi rychle rozšířili po celé zemi, zvláště do západních a jižních Čech. Získali postupně Úterý u Stříbra (1183), Kadaň (1186), Manětín a v devadesátých letech okolí Varvažova u Smetanovy Lhoty u Mirovic. K počátkům johanitů v českých zemích a k založení jejich nejstarší komendy v Praze na Malé Straně nejnověji M. Skopal (1993). Z dalších českých johanitských lokalit je nutno zmínit velký komplex v Českém Dubu (okres Liberec; Vlček-Sommer-Foltýn 1997, 204-206; pro Moravu srov. Mitáček 2010 - zde další literatura). Je velice pravděpodobné, že do tohoto období bude možno zařadit i počátky hradu ve Strakonicích a také kurii v Radomyšli. Hovoří o tom především výsledky archeologických výzkumů posledních desetiletí (Nechvátal v tisku). 


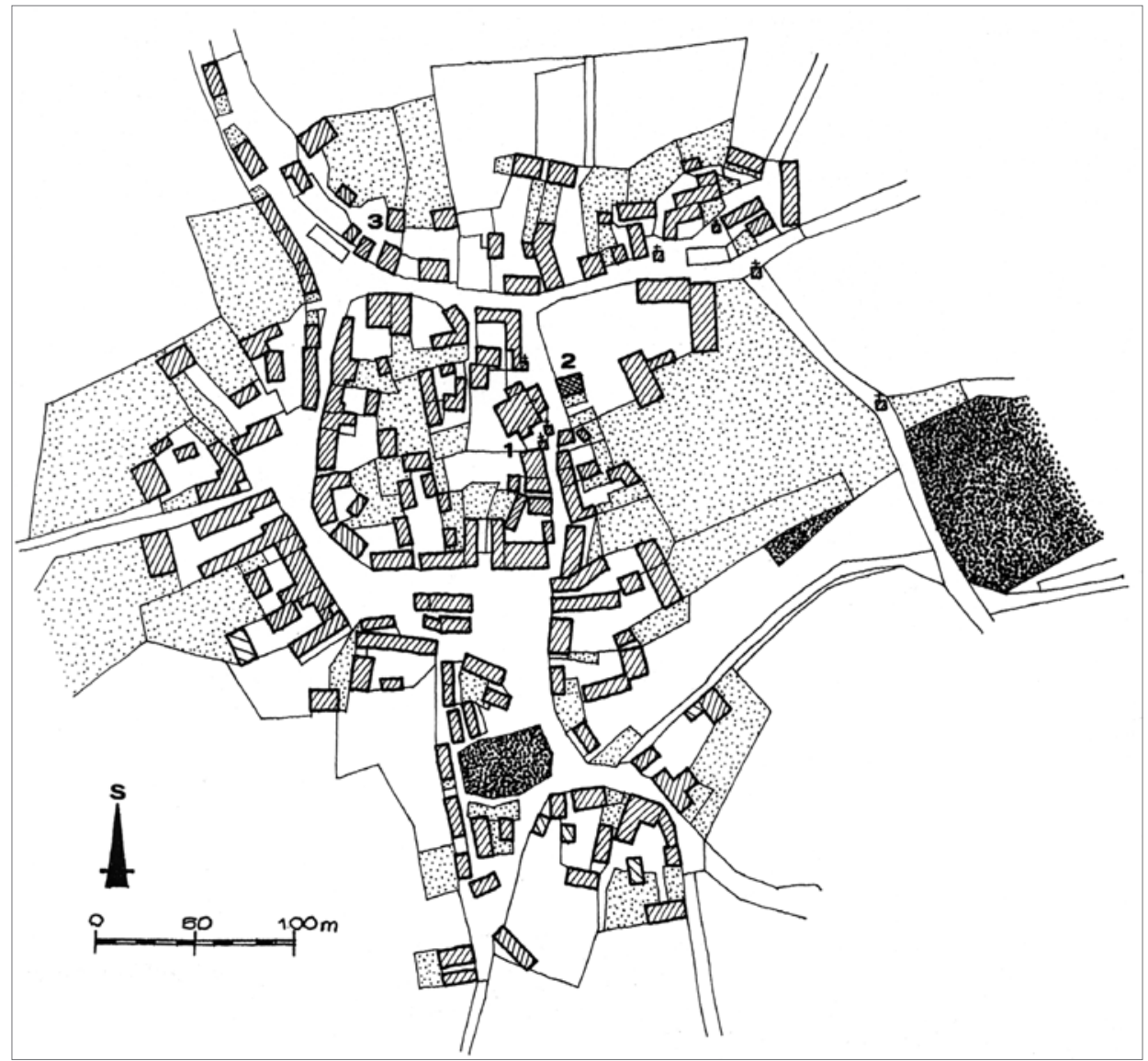

Obr. 3a. Radomyšl - katastrální plán městečka z roku 1837. 1 - místo románského sídla, 2 - situace řádové kurie, 3 - tzv. Trhlíkovský grunt, v roce 1583 hospodářství Adama ze Škvorce.

Abb. 3a. Radomyšl - Katasterplan des Städtchens aus dem Jahr 1837. 1 - Stelle des romanischen Sitzes, 2 - Situation der Ordenskurie, 3 - sog. Trhlík-Anwesen, im Jahr 1583 Gutshof von Adam von Škvorec.

III.

Při rekonstrukci podoby a vzhledu románské sakrální stavby (obr. 4) byly důležité terénní situace u řezu 20, 28 při výkopu sondy S-2/68. V sondě, která byla na jižní straně románské empory, byly $\mathrm{v}$ její horní části zjištěny mladší hroby. Byla zde nalezena řada nálezů ze skleněných zbrušovaných koleček, které byly většinou umístěny v místech spánkové kosti. Ve spodní vrstvě hrobů (hroby č. 88/68-100/68) byly zjištěny stratigraficky starší hroby, u nichž však nelze plně prokázat mladohradištní charakter. Chybí nálezy a základní charakteristiky ritu tohoto období. Hroby č. 93/68-100/68 byly uloženy v sytě tmavě hnědé až černé vrstvě, která byla promísena keramikou, kostmi a drobnými uhlíky. Charakter keramiky je možno rámcově označit za vyspělý, pozdně mladohradištní materiál. Jsou zde tvary s málo vytaženým nečleněným okrajem, který mají archaický charakter profilu, ale i ryté výzdoby (Nechvátal 1999, 37-39). Po vybrání této vrstvy, která naznačovala možnost, že jsme v interiéru sídlištního objektu, se objevil systém mohutných jam po kůlech o průměru $30-35 \mathrm{~cm}$, které byly odděleny od vlastního objektu ostrým hlubokým žlabem $(40-50 \mathrm{~cm})$. Za ním terén prudce spadal a na dně dosahoval $270-280 \mathrm{~cm}$ 


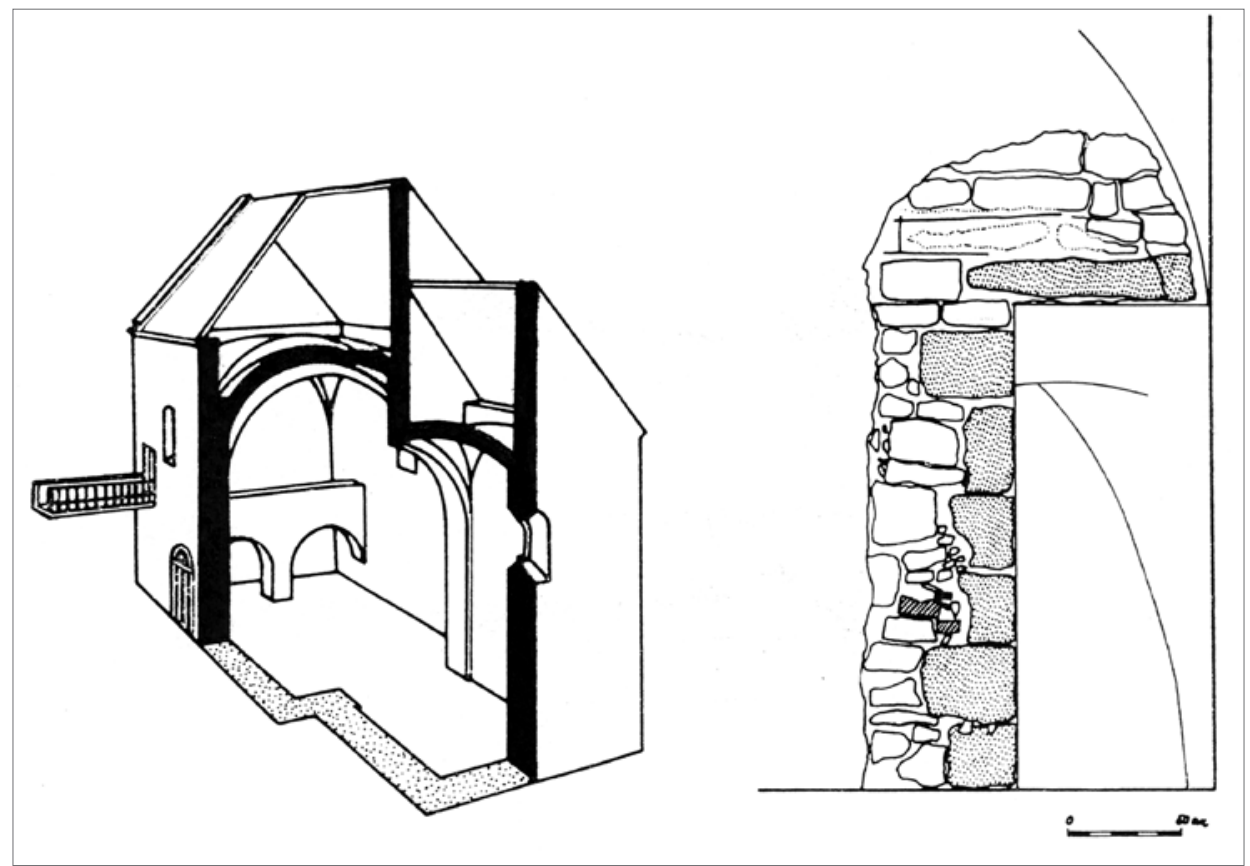

Obr. 4. Rekonstrukce románského kostela sv. Martina v Radomyšli - řez s pohledem k panské tribuně. Rekonstrukci na základě archeologického, historického a stavebního průzkumu provedl F. Kašička.

Abb. 4. Rekonstruktion der romanischen Kirche St. Martin in Radomyšl-Schnitt mit Blick zur Herrenempore. Die anhand der archäologischen, historischen und baulichen Untersuchung erfolgte Rekonstruktion stammt von F. Kašička.

hloubky od povrchu terénu. Sonda S-2/68 o rozměrech $8 \times 3 \mathrm{~m}$ nemohla již býti prodloužena více k jihu pro zkoumání tohoto objektu, protože by ohrožovala základy sousedního domu. Dům v Kostelní ulici čp. 83, který je rodným domem bibliotekáře Náprstkova muzea a historika Radomyšle B. Lifky (1900-1987), byl původně v roce 1833 založen významným purkmistrem (1826-1862) Janem Bočounem (1794-1862) a byl vystavěn v klasicistním slohu; má dvoupatrové sklepy.

Fakt, že stavba je v př́mé ose původního vchodu na románskou emporu a keramika, která $\mathrm{v}$ něm byla nalezena, je současná s předpokládanou dobou života románské tvrze, nás vede $\mathrm{k}$ interpretaci, že jsme v prostředí románského šlechtického sídla. Na základě stáŕí této části kostela musíme označit za velmi pravděpodobnou skutečnost, že jsme u základů románské tvrze, která však v této fázi, jak zjišt’ujeme, byla vybudována ze dřeva. Pro tuto možnost interpretace svědčí i značná vzdálenost (12-14 m) od vlastního vchodu na emporu. Stavbu datujeme do rozmezí od druhé poloviny 12 . století až do průběhu první poloviny 13 . století.

V další etapě poznání podoby johanitské kurie v Radomyšli lze rozpoznat její přesun východním směrem. Označujeme ji jako stavební objekt O-1. Na jižní straně pohřebiště byly v roce 1963 zjištěny středověké objekty. Na východní straně pohřebiště byla část hrobů překryta černou popelovitou vrstvou, do níž byl také zahlouben stavební objekt O-1. Vrstva narůstala potom s nejstarší funkční fází tohoto objektu. Jeho počátky byly datovány do průběhu 13. století, spíše do jeho druhé poloviny. Stavba porušuje některé z hrobů (hroby č. 158/63, 159/63 a 196/63). Je téměř čtvercového půdorysu o rozměrech přibližně $8,90 \times 8,60 \mathrm{~m}$. Má dva opěrné pilíře na severní straně. Síla obvodového zdiva kolísá v rozmezí $140-150 \mathrm{~cm}$, bez vnitřního členění prostoru. Na jižní straně stavby je částečně zachován záklenek, který byl po ztrátě původní funkce zasypán. 


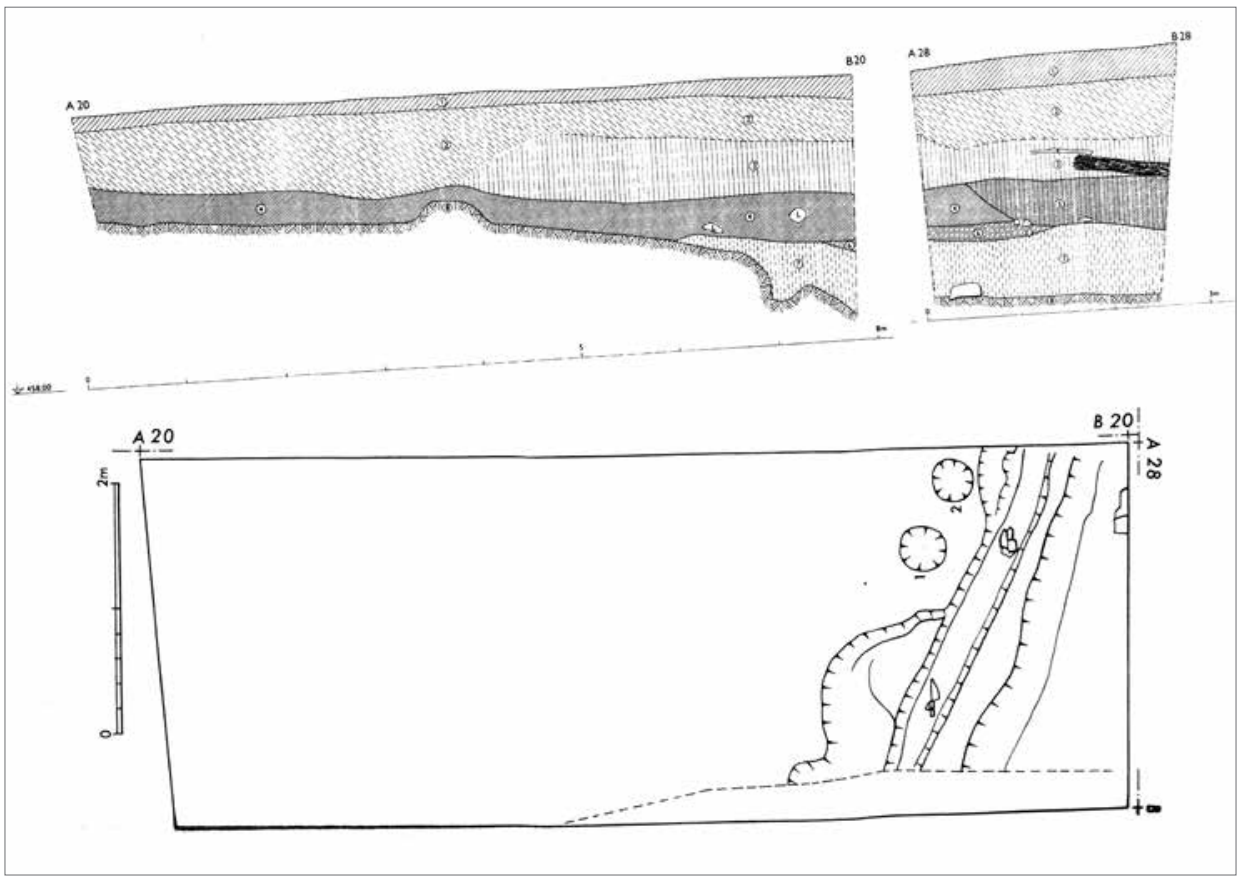

Obr. 5. Řezy 20, 28 - východní a jižní profil a půdorys sondy S-2/68. Popis vrstev. 1 - humus, 2 - šedohnědá, hlinitá s úlomky cihel, kamene a lidských kostí z rozrušených hrobủ, 3 - tmavě šedohnědá s roztroušenými uhlíky, 4 - světle šedá hlinitá s úlomky vápna, 5 - tmavě hnědá s uhlíky a s drobnými zrnky vápna, 6 - světle šedá, hlinitá $s$ kousky vápna a rezavě šedými zrnitými zlomky vápenné mazanice a úlomky vápencových kamenů, 7 - tmavě hnědá s drobným kamením, se stopami uhlíkủ a sídlištní keramikou, 8 - rezavě hnědá, hlinitá - rostlý terén, $\mathbf{L}$ - lebka. Celková terénní situace naznačuje polohu románského šlechtického sídla.

Abb. 5. Schnitte 20, 28 - Ost- und Südprofil und Grundriss Sondierschnitt S-2/68. Beschreibung der Schichten: 1 - Humus, 2 - grau-braun, lehmartig mit Ziegelbruchstücken, Steinen und menschlichen Knochen aus gestörten Gräbern, 3 - dunkelgrau-braun mit verstreuter Holzkohle, 4 - hellgrau lehmartig mit Kalkbruchstücken, 5 - dunkelbraun mit Holzkohle und Kalkkörnchen, 6 - hellgrau, lehmartig mit Kalkstücken und rostgrauen körnigen Lehmbewurfbruchstücken und Kalksteinbruchstücken, 7 - dunkelbraun mit Kleingestein, Holzkohlespuren und Siedlungskeramik, 8 - rostbraun, lehmartig gewachsenes Gelände, L - Schädel. Die gesamte Geländesituation deutet die Lage des romanischen Adelssitzes an.

V zásypu se objevují amorfní stavební články, které by snad bylo možno zařadit do pozdně barokního období. Je to například torzo kamenného podstavce od kříže a jiné. Vnitřní lícování zdiva, především na východní straně napodobuje ve značně zhrublém stylu nepravidelně kvádříkový, pozdně románský systém zdiva, jak při stavební komisi v říjnu 1963 upozornil přední znalec románské architektury Václav Mencl (1905-1978).

Vlastní zdivo má vyhřezlé spáry, bylo stavěno do šachty na šedavě bílou vápennou maltu. Výška dochovaného zdiva objektu, který byl úplně skryt pod úrovní dnešního terénu, dosahovala místy především na východní a jižní straně $2,20-2,45 \mathrm{~m}$. Jižní obvodové zdivo stavby bylo použito později, když byl objekt rozšířen na vzácný typ tř́íprostorové johanitské kurie. Později, když při přestavbě ztratil původní funkci, byl přestavěn na pozdně barokní špýchárek. Blízkost kostela a skutečnost, že osa odkrytého objektu je rovnoběžná s osou kostela, umožňují interpretaci stavby jako tvrze patronátního charakteru, později johanitské kurie nejstarší v českých zemích. Středověké stavby udávají datum nejstarší meze funkce hřbitova na prozkoumaném místě. Je tř̌eba uvážit, že musely být postaveny až po delším čase, kdy pohřbívání na této části lokality skončilo. Tyto skutečnosti bylo třeba bráti v úvahu při celkových chronologických souvislostech. 


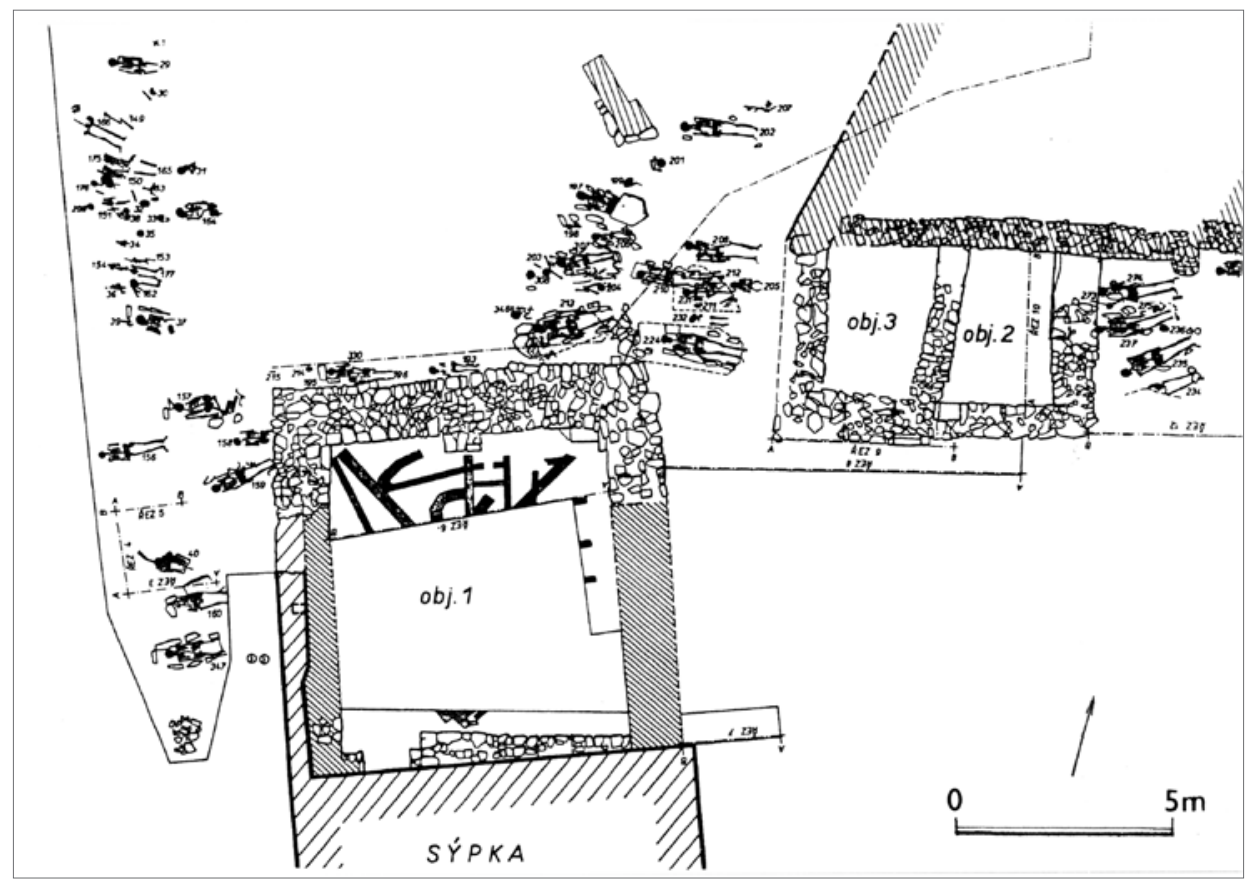

Obr. 6. Radomyšl - středověké objekty O-1 (johanitská kurie), O-2, O-3.

Abb. 6. Radomyšl - mittelalterliche Objekte O-1 (johannitische Kurie), O-2, 0-3.

V případě stavebního objektu O-1 šlo patrně o věžovitý objekt s dřevěnou konstrukcí. Stav trámů nebyl dobrý, nebylo možno odebrat vzorky na dendrochronologickou analýzu.

Rozsah johanitské kurie v Radomyšli se zázemím byl patrně větších rozměrů, jak by mohl svědčit ještě nejstarší katastrální plán z roku 1837; především na západní straně (obr. 3a; k tomu srov. Kuča 2004, 276-280; též Mencl 1980, 166-167). V roce 1320 daroval Vilém Bavor ze Strakonic faru s kostelem johanitům. V roce 1359 jim odkázal spolu s manželkou Markétou celé městečko, které bylo v držení maltézského řádu až do roku 1848.

O funkčním použití stavby v pozdní době svědčí zprávy maltézských velkopřevorů, ještě k roku 1752 je o něm zpráva $\mathrm{v}$ inventáři kostela a fary, který byl pravděpodobně prací faráře Frà Jakuba Heyduka. Podle tohoto latinského zápisu sloužila budova staré johanitské, později maltézské kurie po třicetileté válce zřejmě stavebně zabezpečená nejdříve jako obydlí kaplana a v době soupisu inventáře jako útočiště mendíků - žebravých studentů. Nadále se v této době používala spojovací lávka $\mathrm{s}$ dvěma zachovanými krakorci $\mathrm{z}$ objektu ke šnekovému schodišti kostela nad sakristii v severní lodi. Zápis identifikuje jeden $\mathrm{z}$ objektů poblíž kurie jako pozdější součást farského pivovaru. Bylo již konstatováno v době výzkumu v roce 1963, že technické a bezpečnostní př́činy a rychlý postup stavby v pozdějším období dovolily odkrýt podlahu objektu jenom z jedné třetiny, význam objektu zasluhoval prozkoumání úplné.

Keramika z černé popelovité vrstvy i u stavebního objektu O-1 je charakterizována silnostěnným střepem, jde převážně o zlomky užitkových nádob, hrnců větší a střední velikosti, pokliček miskovitého tvaru se širokým knoflíkem a různé fragmenty velkých tuhových zásobnic. Je poměrně bohatě zdobena a jako výrazných prvků je použito kapkovitých vpichů v celé řadě variant, vlnovky a ryté převážně vývalkovité šroubovice. Podsypávaná dna nádob jsou často opatřena hrnčírskou značkou, objevují se i případy kolkování, především u tuhovaných 
zásobnic. Celý soubor má základní charakteristiku vyspělého pozdně mladohradištního období, jak je zjišt’ujeme u celé řady keramiky datované mincemi (Radoměrský-Richter 1974, 62).

Z objektu johanitské kurie také pochází dlaždice s plastickou výzdobou v podobě lilií datovatelná do 14. století a drobné zlomky dalších. Ve Štítkově (okres Prachatice) byl nalezen stejný typ, který pochází z místní tvrze. Nálezová situace ověřená J. Fröhlichem umožňuje jeho datování již do 13. století (Fröhlich 1989, 327-330). Další dlaždice s motivem s lilií a hvězdicemi byla $\mathrm{v}$ Radomyšli nalezena $\mathrm{v}$ druhotné poloze $\mathrm{v}$ prvním patře $\mathrm{v}$ komoře nad sakristií (Nechvátal 1999, 157, obr. 123).

Zcela mimořádným nálezem bylo středověké aquamanile ze zásypové vrstvy u johanitské kurie. Při její interpretaci (obr. 20) je především nutno zdůraznit motiv beránka ve smyslu křest’anské představy a ideálu - Beránek Boží - snímá hříchy světa. Biblický motiv doložený již v Apokalypse, ale i jinde, např́íklad křest Kristův sv. Janem Křtitelem (Bible 1979, 968, 972 n.), je znám v nejstarším křestanském umění a dále po celý středověk až do novověku.

Stavba johanitské kurie $\mathrm{v}$ druhé polovině 14. století byla zcela mimořádným objektem z doby předhusitské, vzácně zachovaná ze dvou třetin v barokním plášti špýchárku. Kromě původního objektu O-1, který později zanikl, jak ukazuje jeho stratigrafická situace. Později došlo $\mathrm{k}$ jeho obnově (srov. vrstvu $4 \mathrm{v}$ profilu vyobrazeném na obr. 7). Zachovaná stavba ve špýchárku je rozdělena na dvě části, severní 7,5-3,8 m a jižní 6,8-3,8 m. Stala se vdovským sídlem Markéty ze Šternberka, která byla vdovou po Vilému Bavorovi ze Strakonic (před rokem 1375). Objekt byl pravděpodobně rozdělen na část světskou a církevní. Vlastní rozdělení neznáme.

Někdy kolem roku 1375 Vilémova vdova Markéta, dcera Štěpána ze Šternberka, zemřela. Desetiletí před tím, v roce 1365, Karel IV. potvrzuje Albrechtovi, biskupu litoměřickému, městečko a tvrz Bělčice, ves Lhotu a tvrz Kozlov, které mu Markéta ze Strakonic, jeho sestra, zapsala do zástavy v 200 kopách grošů. Ovdověla patrně roku 1359. Jejím vdovským sídlem byla farní komenda v Radomyšli, kde také pobírala požitky ze svých bělčických statků. Bylo tomu tak ještě v letech 1372-1375. S jejím jménem je také někdy spojována druhá gotická přestavba kostela sv. Martina v Radomyšli za účasti faráře Beneše (1372-1388), jehož stavební činnost

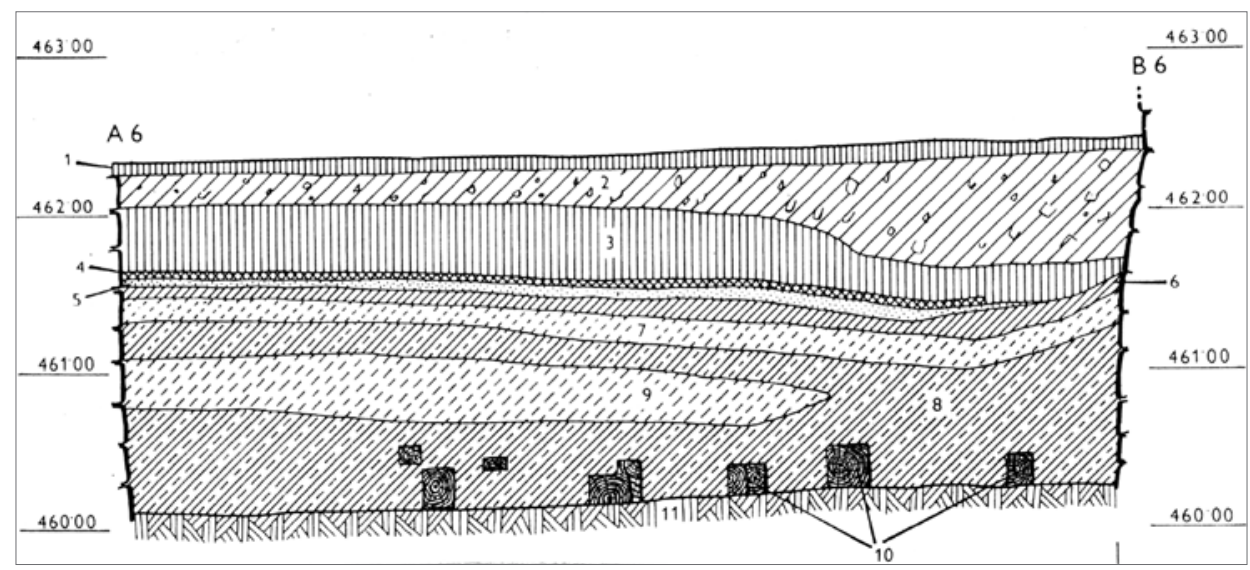

Obr. 7. Radomyšl - profil č. 6 z interiéru středověkého objektu O-1 (johanitská kurie). 1 - humus, 2 - drobné kaménky a kameny, které v západní části splývají v destrukci zdiva, 3 - vrstva hnědé (siena) hlíny, 4 - cihlová podlaha, 5 - maltová vrstva se zrnitým pískem, 6 - vrstva tmavě šedé hlíny, 7 - vrstva světle šedé hlíny se zrnky vápna, 8 - vrstva tmavě šedé hlíny se světlejšími odstíny, 9 - vrstva světle šedé hlíny, dřevěné trámy, 10 - dřevěné trámy, 11 - rostlý terén.

Abb. 7. Radomyšı - Profil Nr. 6 vom Innenraum des mittelalterlichen Objektes O-1 (johannitische Kurie). 1 - Humus, 2 - Steinchen und Steine, die im Westteil in die Zerstörungsschicht des Mauerwerks übergehen, 3 - braune (siena) Lehmschicht, 4-Backsteinboden, 5 - Mörtelschicht mit körnigem Sand, 6 - dunkelgraue Lehmschicht, 7 - hellgraue Lehmschicht mit Kalkkörnern, 8 - dunkelgraue Lehmschicht mit helleren Schattierungen, 9 - hellgraue Lehmschicht, Holzbalken, 10 Holzbalken, 11 - gewachsenes Gelände. 


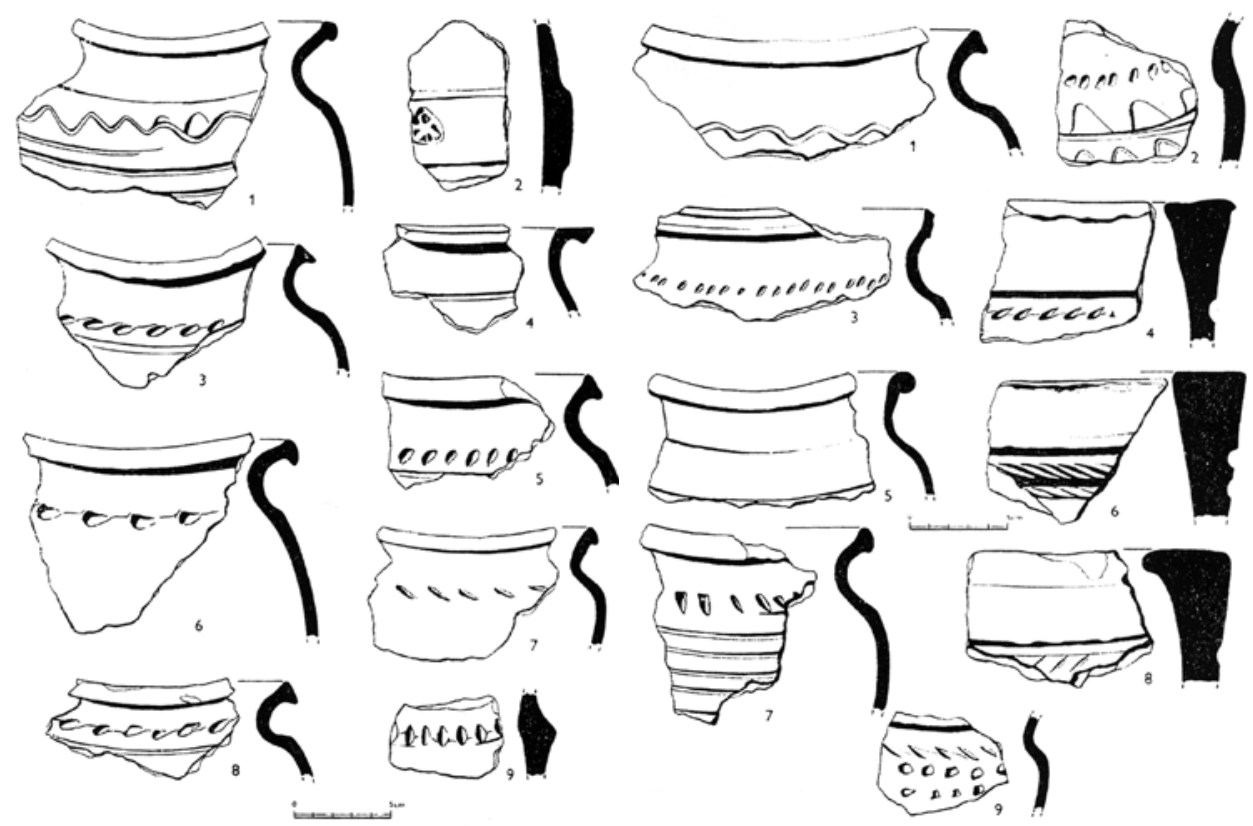

Obr. 8. Keramika z vrstvy, do které byl založen středověký objekt (O-1), johanitská kurie, konec 12. století až průběh 13. století. Kresba M. Chyská.

Abb. 8. Keramik aus der Schicht, in welcher das mittelalterliche Objekt (O-1), die johannitische Kurie, in der Zeit zwischen Ende 12. bis Verlauf 13. Jahrhundert gegründet wurde. Zeichnung M. Chyská.

velmi ocenil arcibiskup Jan z Jenštějna udělením pravomocných odpustků v širokém rozsahu. S Markétou ze Šternberka je spojován znak šternberské hvězdy v centrální ose na gotické křtitelnici, v jižní předsíni kostela sv. Martina je také i na erbovní kartuši ve svorníku v jižní lodi.

Stavební výzkum byl proveden pracovníky NPÚ, územního odborného pracoviště v Českých Budějovicích (Jiří Bloch, Jan Eliška, Lenka Vejvodová), kteři dokumentovali přeměnu johanitské kurie $\mathrm{v}$ barokní špýchárek s cennými stavebními podrobnostmi. Bylo konstatováno dlouhodobé zanedbání údržby této cenné stavební památky jejím majitelem a hodnota stavby nebyla doceněna ani odborem památkové péče Městského úřadu ve Strakonicích. Mimo špýchárek bylo starším archeologickým výzkumem u jihovýchodního nároží zjištěna poměrně mělce zahloubená zídka o šířce 40-50 cm založená již na skalnatém podloží. Původní účel zídky nebyl zjištěn. Snad se jednalo o ohrazení děkanského dvorce, k datování se také nebylo možno vyjádřit. Již zmíněné maltézské vizitační protokoly z let 1591 a 1610, uvádějící spojovací můstek mezi kostelem a johanitskou kurií, jsou podstatným př́spěvkem k stavebnímu vývoji kurie. Při přestavbě kurie na barokní špýchárek byly změněny v rámci komunikace jednotlivé vstupy, což dokládá plánová dokumentace. Kromě popisu stávajícího stavu je možno upozornit na zazděné okénko v přízemí západní části jižní stěny (v jižní místnosti) a torzo dalšího, které jednoznačně svědčí o skutečnosti, že původní prostor byl vyšší. Malé niky o průměrné šířce $43 \mathrm{~cm}$, výšce $37 \mathrm{~cm}$ a hloubce $23-25 \mathrm{~cm}$ jsou pozorovatelné jak na severní, tak na jižní straně. V současné době je zdivo omítnuto, takže další výzkum není možný. Při stavebním výzkumu byla u jižní místnosti u východní stěny zjištěna masivnější jižní část, která vystupovala zhruba $87 \mathrm{~cm}$ nad horizont podlahy. $Z$ dalších zjištění je třeba upozornit na stopy výrazného očazení v severní místnosti na jižní stěně, které by mohly souviset se zde umístěným topeništěm. Vlastní stopy topeniště se nezachovaly. 


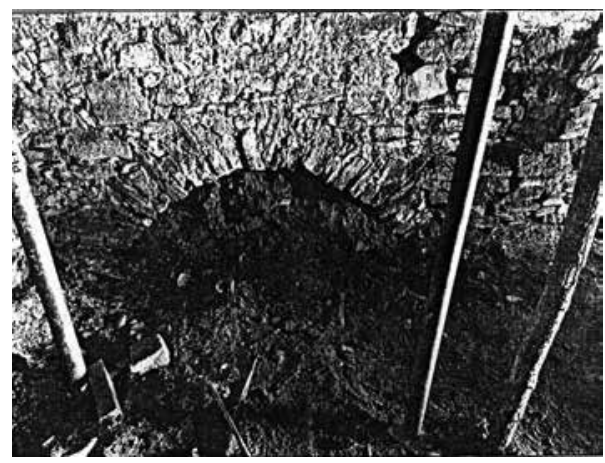

Obr. 9. Záklenek v západní části severní stěny v severní místnosti, na pravé straně výrazná hluboká spára. Foto J. Hloch et. al.

Abb. 9. Bogen im Westteil der Nordwand im nördlichen Raum, auf der rechten Seite ein deutlich tiefer Spalt. Foto J. Hloch et. al.

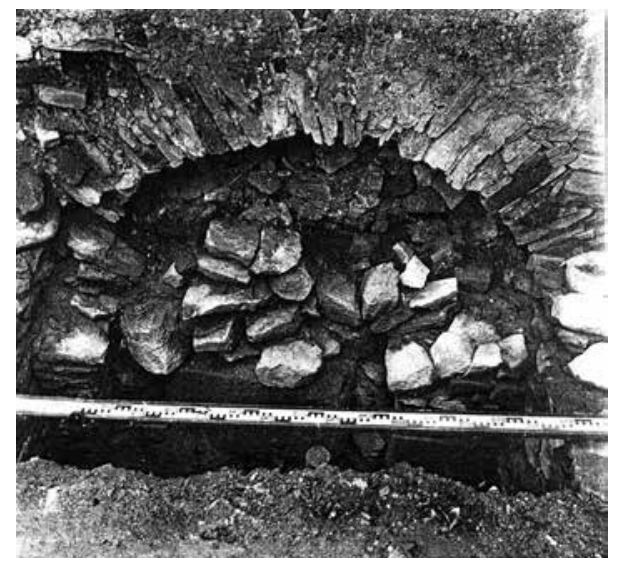

Obr. 10. Zasypaný vchod a záklenek do severní části O-1 (johanitská kurie) odkrytý výzkumem v roce 1963, pohled od severu. Foto B. Nechvátal.

Abb. 10. Im Jahre 1963 bei einer Grabung freigelegter, in den Nordteil von Objekt O-1 (johannitsche Kurie) führender verschütteter Eingang und Bogen, Blick von Norden. Foto B. Nechvátal. šli, nebylo zdivo dokumentováno fotogrammetricky a že by bylo žádoucí provedení většího počtu dendrochronologických analýz. I když dokumentace fotografická je velmi dobré kvality, v žádném př́ípadě nenahradí fotogrammetrii. Rozdílnost šiř́ky zdiva u jižní místnosti ve srovnání se severní místností je možno vysvětlit tím, že severní obvodová zed' sloužila jako příčka $\mathrm{v}$ určité fázi, když v době své vrcholné existence byla kurie tříprostorová.

Nejbližší johanitská kurie byla v Horažd'ovicích, ta byla zničena v době předhusitské (Němec 1936), asanační práce v 19. a 20. století zatím nezjistily její polohu. Byla vzdálena $18 \mathrm{~km}$ severozápadním směrem od Strakonic.

V areálu farního děkanského dvorce byl v jeho jižní a jihovýchodní části zjištěn rozsáhlý komplex sklepů. Byl vzdálen 17 m severovýchodním směrem od severního nároží dnešní budovy farního děkanství v Radomyšli. Celý komplex byl v roce 1963 - v době archeologického průzkumu pohřebiště - zaměřen arch. Eugenem Pochitonovem (1902-1991), pracovníkem Národního 
muzea v Praze. Dochovaná dokumentace zaměření je pouhým technickým elaborátem ve formě měřické skici s dílčími nepřesnostmi, které byly dány vzrůstajícími časovými nároky v době výzkumu pohřebiště, jehož stav byl drasticky ohrožen stavbou pohostinství Jednoty Volyně.

Komplex sklepů značného rozsahu je mimo budovu dnešního děkanství směrem severovýchodním v areálu děkanského dvorce. Poměrně rozsáhlý komplex má rozměry přibližně (v ose západ-východ) $23 \times 15 \mathrm{~m}$. Na celkovém plánu archeologického výzkumu pohřebiště, kostela a sídlištních objektů se nachází ve střední části. Na jihu je ohraničen sondami S-5/63 a S-6/63, na západní straně rozsáhlým sektorem S-4/63, na severu a východě S-M/64 a S-K/64. Jeho severní strana je ohraničena torzálním základovým zdivem, které bylo bagrováním z velké části zcela zničeno (Nechvátal 1999, 31, obr. 12). Původně bylo označeno jako torzo barokní stodoly, která na nejstarší katastrální mapě z roku 1837 není již vyznačena. Na základě nově zjištěných a celkových souvislostí ho považujeme za základové zdivo fary z rozsáhlé činnosti Mikuláše Kř́ižka, který byl správcem fary v letech 1540-1570. Později velkopřevorem ve Strakonicích, v této funkci setrval až do roku 1590, kdy ho vystřídal Jiří Hlivický. Křížkova stavební činnost byla značná - přestavba, vlastně novostavba poutního maltézského kostela sv. Jana Křtitele nad Radomyšlí a velká rekonstrukce farního kostela sv. Martina ve vlastním městečku. Kř́žkův portrét (z roku 1568) je uložen ve velmi špatném stavu v kostele sv. Jana Křtitele.

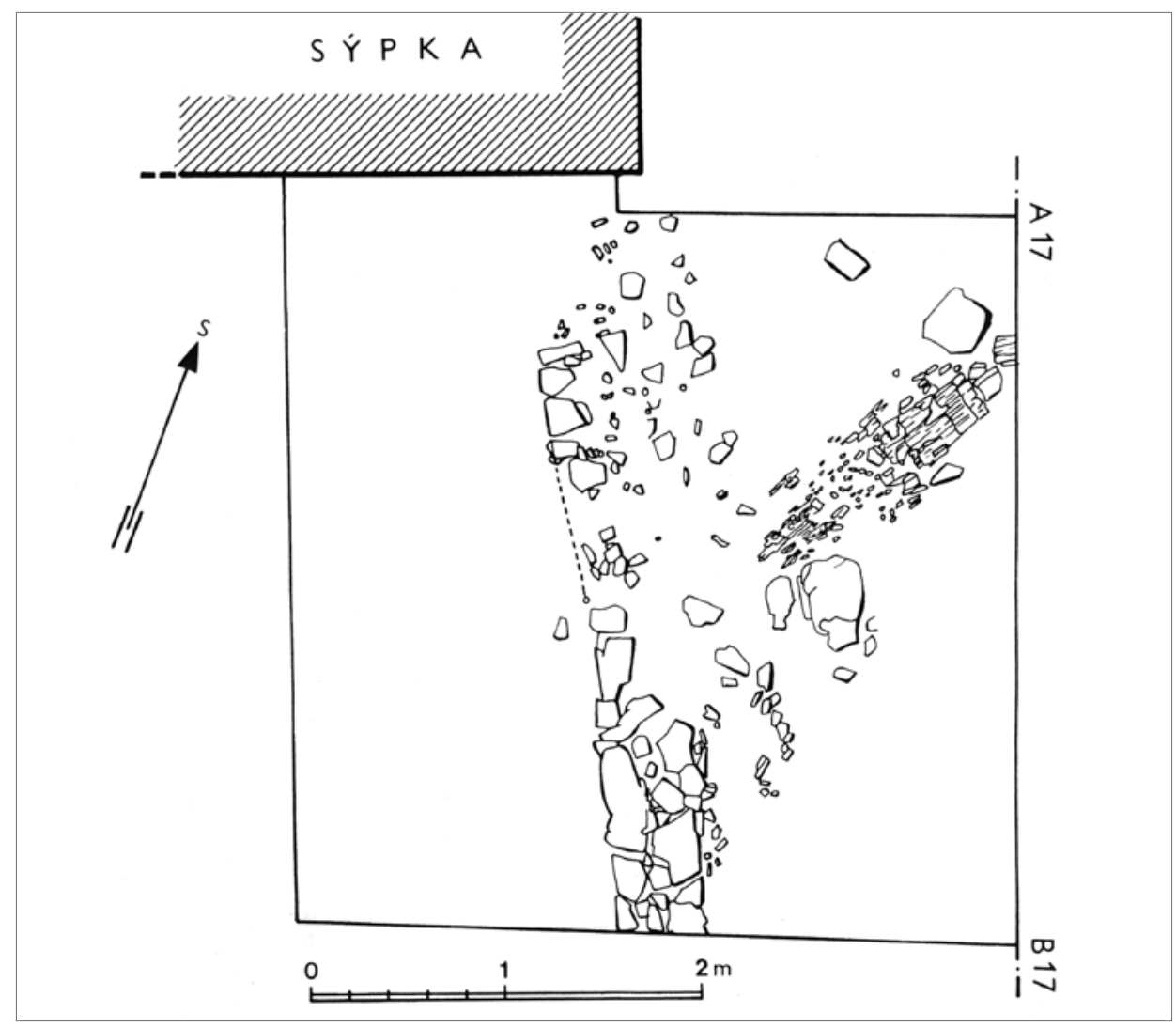

Obr. 11. Sektor S-L/64 - půdorys základového zdiva ohradní zídky př̌i jihovýchodním nároží špýchárku, zjištěný archeologickým výzkumem v roce 1963. Zdroj archiv AV ČR, Praha, v. v. i.

Abb. 11. Sektor S-L/64 - Grundriss des Fundamentmauerwerks der während der archäologischen Grabung im Jahr 1963 entdeckten kleinen Begrenzungsmauer an der südöstlichen Ecke des Getreidespeichers. Quelle Archiv der Tschechischen Akademie der Wissenschaften, Prag. 


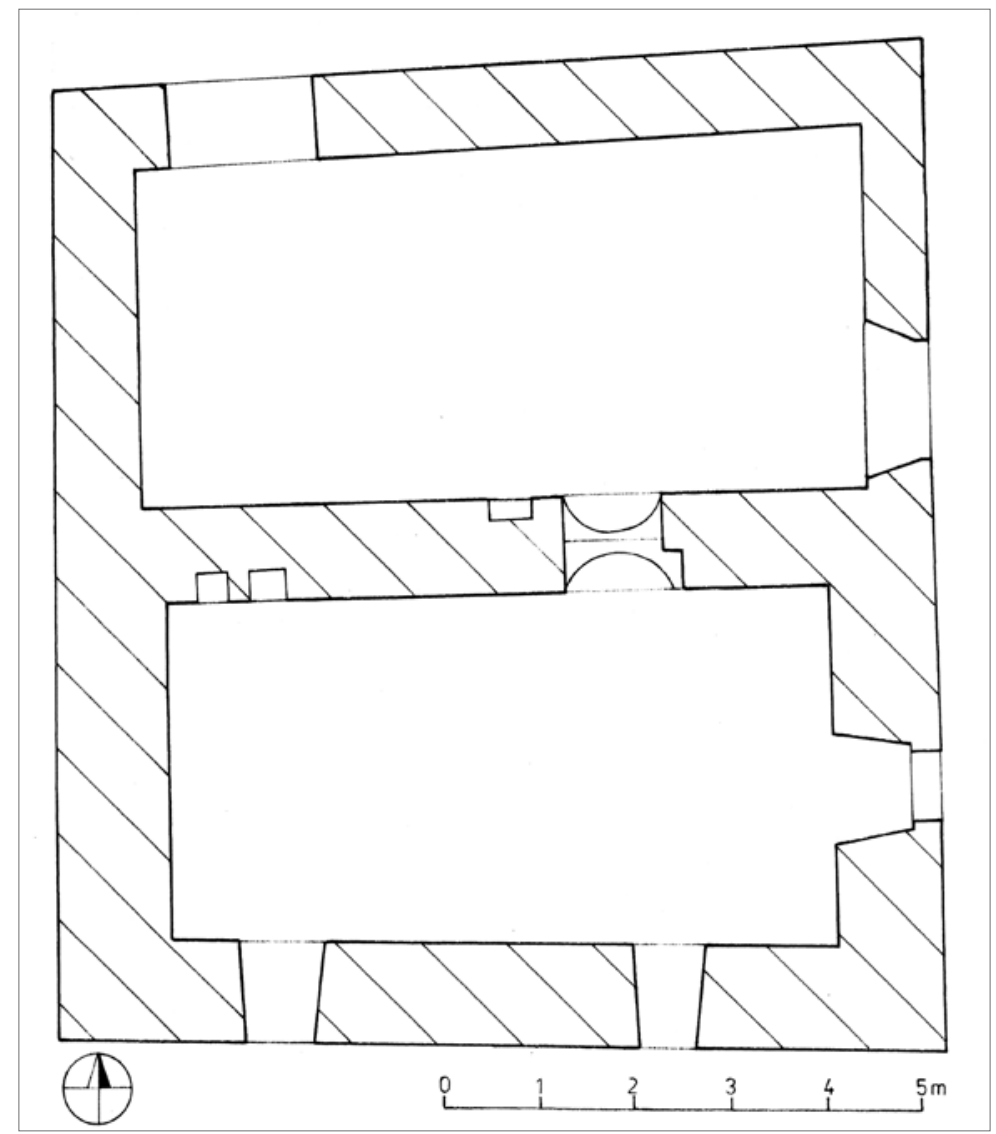

Obr. 12. Půdorys johanitské kurie v Radomyšli - severní a jižní místnost. Podle Bloch-EliškaVejvodová 2015-2016, upraveno.

Abb. 12. Grundriss der johannitischen Kurie in Radomyšl - Nord- und Südraum. Nach BlochEliška-Vejvodová 2015-2016, bearbeitet.

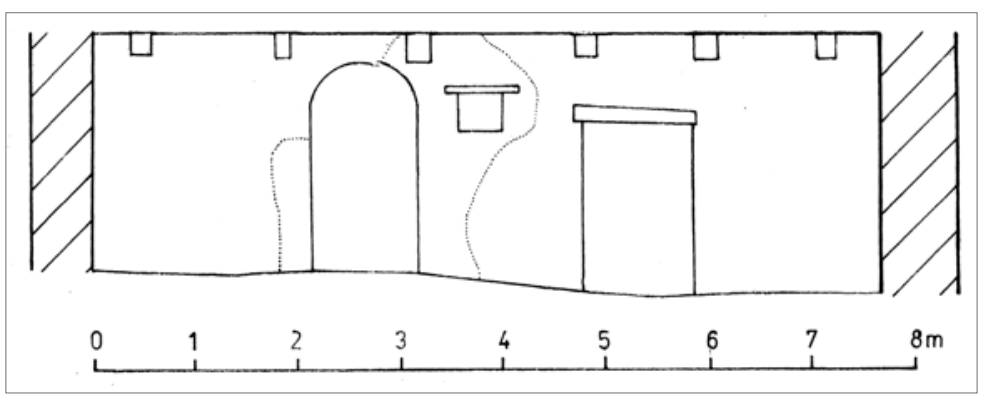

Obr. 13. Pohled od severu na př́čku v severní místnosti. Podle Podle Bloch-Eliška-Vejvodová 2015-2016, upraveno.

Abb. 13. Blick von Norden auf die Trennwand im Nordraum. Nach Bloch-Eliška-Vejvodová 2015-2016, bearbeitet. 


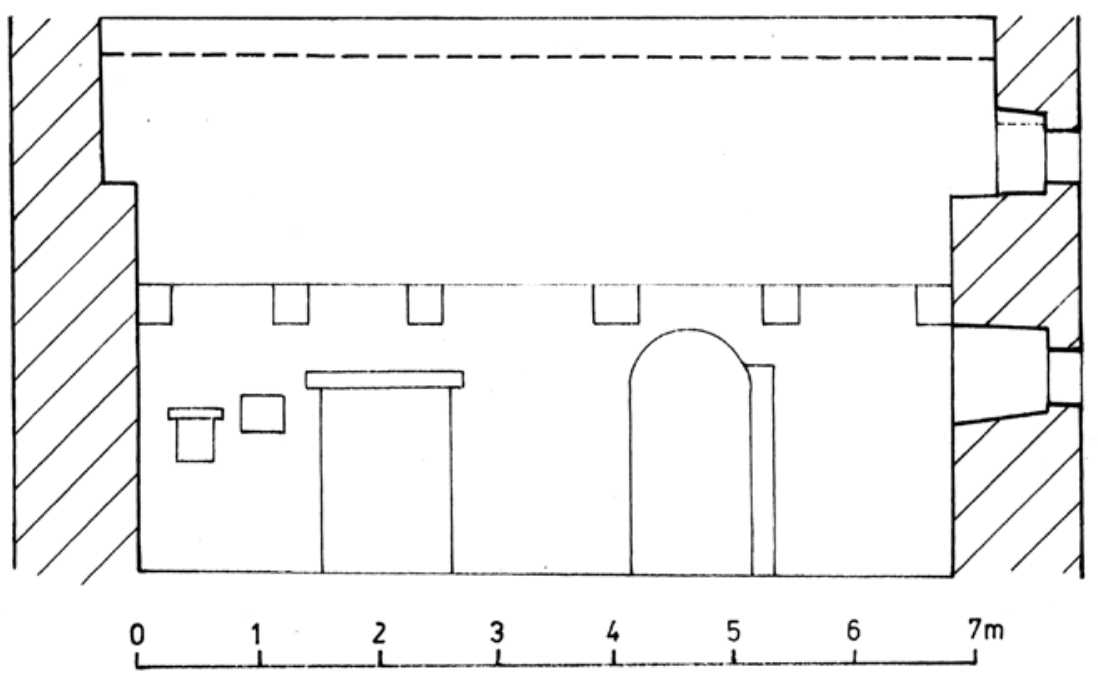

Obr. 14. Pohled od jihu na příčku v jižní místnosti. Podle Bloch-Eliška-Vejvodová 2015-2016, upraveno. Abb. 14. Blick von Süden auf die Trennwand im Südraum. Nach Bloch-Eliška-Vejvodová 2015-2016, bearbeitet.

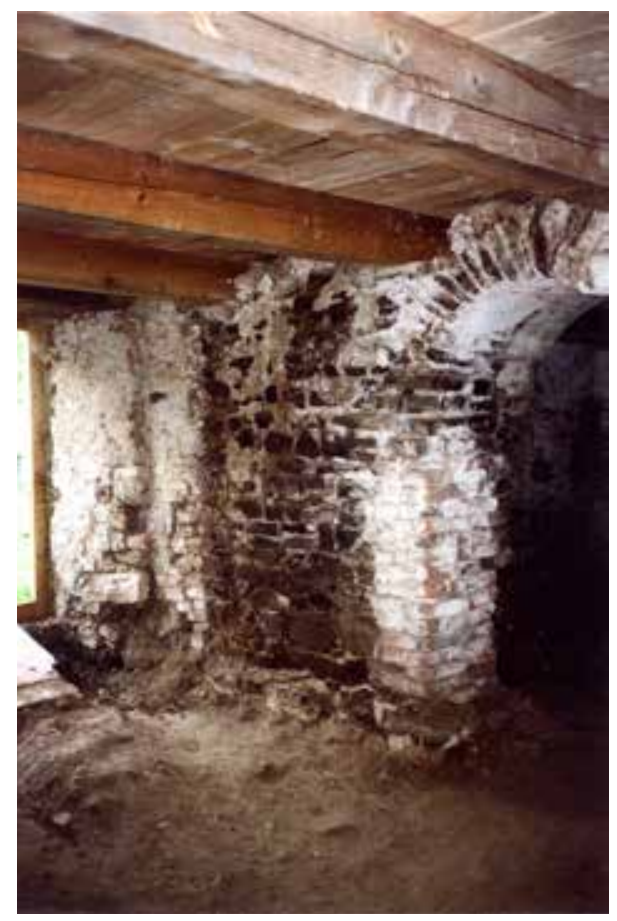

Obr. 15. Pohled od severu na boční vstup ve spojovací příčce. Foto B. Nechvátal.

Abb. 15. Blick von Norden auf den Seiteneingang in der Verbindungstrennwand. Foto B. Nechvátal.
Jižní strana sklepního komplexu, jak již bylo upozorněno, byla nesprávně interpretována jako zdivo barokní stodoly, dnes fary, z doby, kdy byl farářem Mikuláš Kř́ižek. Stavba není doložena na nejstarším katastrálním plánu z roku 1837. Základy renesanční fary byly zjištěny $\mathrm{v}$ řezu 13 , kde je zdivo tvořeno obdélnými kamennými hranolky - kvádry z místní žuly - granodioritu (Nechvátal 1999, 52).

Komplex sklepů je možno rozdělit na dvě vzájemně propojené části, které mohou svědčit o dvou etapách výstavby. Č́st, kterou považujeme za starší, je menším celkem v severovýchodní části komplexu, mírně zahloubena pod úrovní tehdejšího terénu děkanského dvorce, prŕístupna volně z terénu cihelnými schody. Vytváŕí tříprostorový komplex, který měl nejen samostatný vstup, ale byl také spojovacím traktem připojen $\mathrm{k}$,mladšímu“ objektu. Rozměry prvního prostoru byly $4,46 \times 1,80 \mathrm{~m}$. Měl na každé delší straně ve středu stěny malou obdélnou niku $(40 \times 30 \times 25-30 \mathrm{~cm})$. Za spojovacím krčkem následuje střední prostor o nepravidelném zalomeném půdorysu (3,54 až $4,52 \mathrm{~m}$ v podélné ose a šířce ca $1,80 \mathrm{~m})$, který má v druhé části niku o velikosti $40 \times 30 \times 25 \mathrm{~cm}$. Dále 


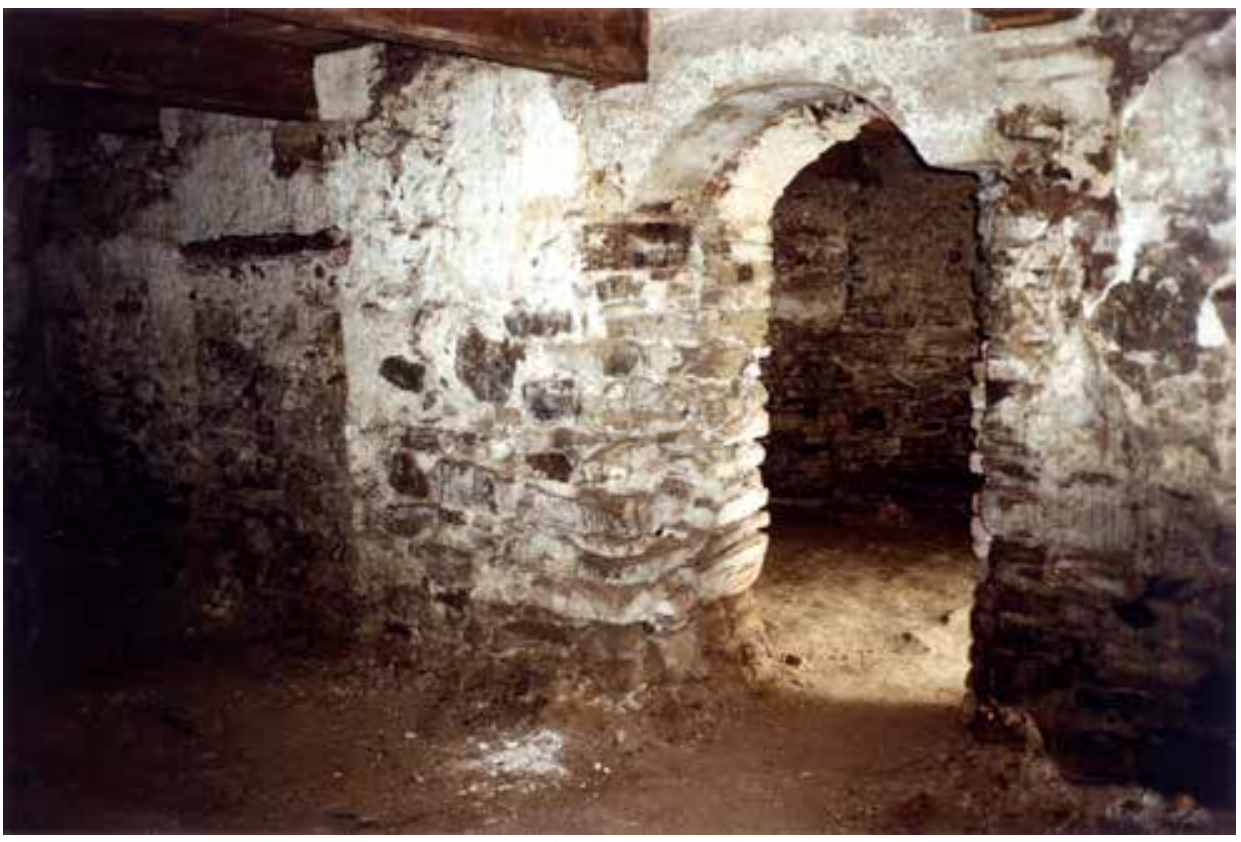

Obr. 16. Pohled od jihovýchodu na boční vstup ve spojovací příčce. Foto B. Nechvátal.

Abb. 16. Blick von Südosten auf den Seiteneingang in der Verbindungstrennwand. Foto B. Nechvátal.

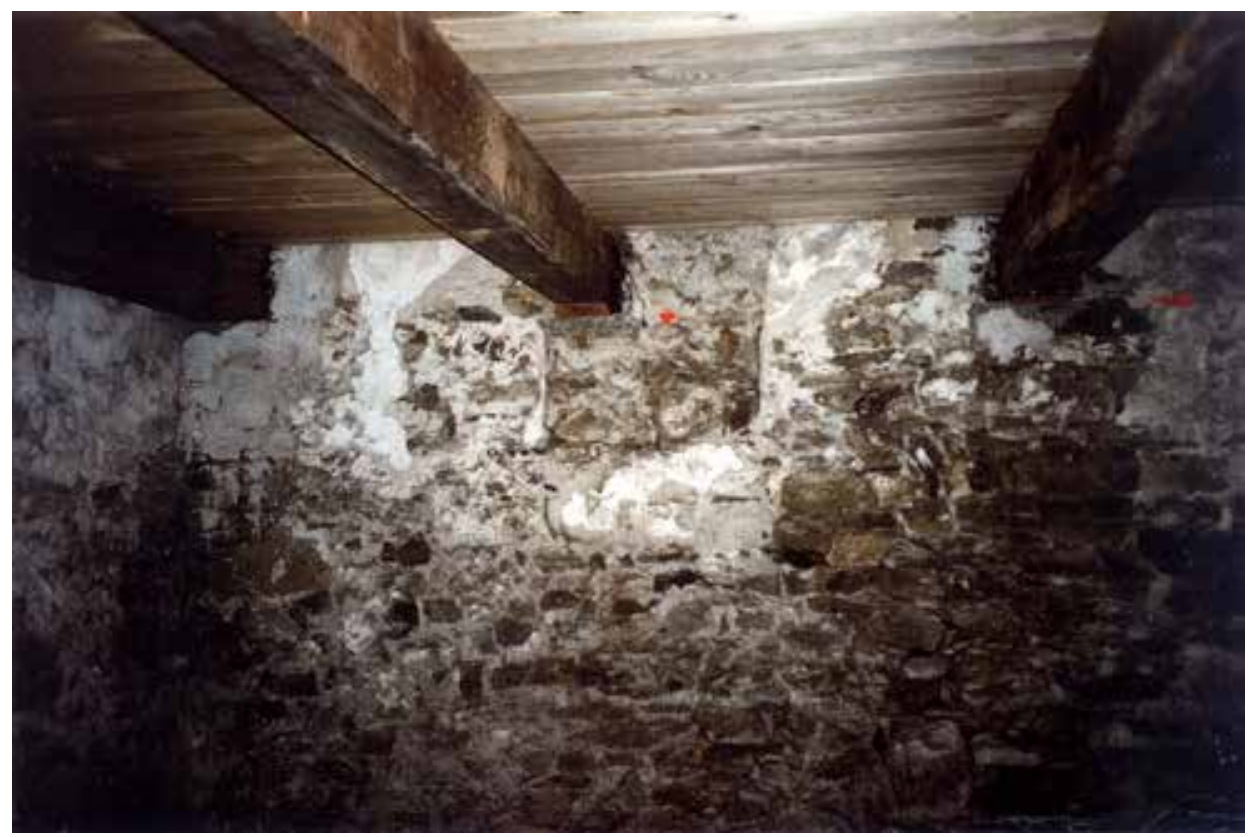

Obr. 17. Pohled od severu na zazděné okénko v přízemí západní části jižní stěny v jižní místnosti. Foto B. Nechvátal.

Abb. 17. Blick von Norden auf die zugemauerte Fensteröffnung im Erdgeschoss des Westteils der Südwand des Südraums. Foto B. Nechvátal. 


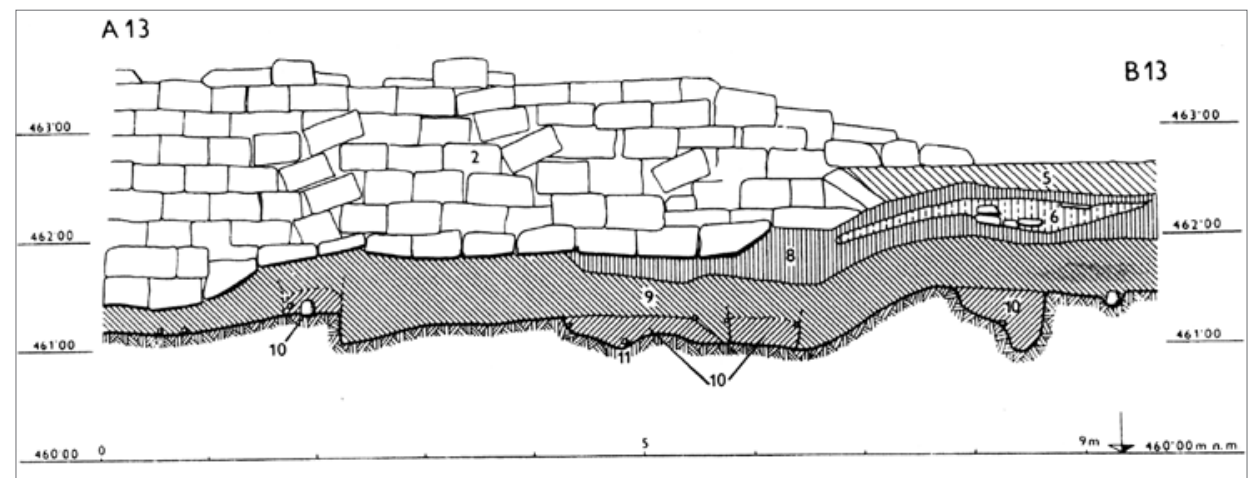

Obr. 18. Profil č. 13 v sektoru S-5/68 v místech základů renesanční fary. Popis vrstev. 1 - humus, 2 - základové zdivo renesanční fary, původ ně považované za barokní stodolu, 3 - světle hlinitá vápenná vrstva, 4 - maltová vápenná výplň $s$ kaménky, 5 - šedohnědá vrstva, 6 - žlutě hnědá jílovitá čočka, 7 - černá humusovitá zemina se sídlištní keramikou nacházející se nad třemi zbytky hrobů, 8 - černá vrstva s uhlíky, 9 - hnědošedá vrstva, 10 - výplň hrobové jámy, 11 - rostlý terén.

Abb. 18. Profil Nr. 13 in Sektor S-5/68 an den Fundamentstellen des renaissancezeitlichen Pfarrhauses. Beschreibung der Schichten: 1 - Humus, 2 - Fundamentmauerwerk des ursprünglich als barocke Scheune angesehenen renaissancezeitlichen Pfarrhauses, 3 - helle lehmartige Kalkschicht, 4 - Mörtel-Kalk-Verfüllung mit Steinchen, 5 - graubraune Schicht, 6 gelb-braune tonhaltige Linse, 7 - schwarzes Humuserdreich mit sich über drei Grabüberresten befindender Siedlungskeramik, 8 - schwarze Schicht mit Holzkohle, 9 - braungraue Schicht, 10 - Grabgrubenverfüllung, 11 - gewachsenes Gelände.

následuje vstupní část o stejné šířce a nepravidelné délce - 3,87 až 2,82 m. Př́stup do druhé části komplexu je po cihelných schodech $\mathrm{v}$ délce $5,94 \mathrm{~m}$. Na jejich konci je nepravidelná nika o rozměrech přibližně $40 \times 30 \times 25-30 \mathrm{~cm}$. Dále následuje vstupní krček v délce $1,38 \mathrm{~m}$, rovněž s malou obdélnou nikou ve středu (ca $40 \times 30 \times 25 \mathrm{~cm}$ ). Podobné odkladové niky, přibližně stejných rozměrů a uložení, byly zjištěny při archeologickém výzkumu v roce 1963 u stavebního objektu O-1, O-2. Jeho východní stěna, kde byla nika umístěna, měla vnitřní lícování napodobující ve značně zhrublém stylu nepravidelně kvádříkový, pozdně románský systém vazby zdiva.

V další části se sklepní komplex rozevírá do tř́i prostor. Levý má vstupní část o délce $2,63 \mathrm{~m}$, která je zakončena čtvercovým prostorem (ca $1,80 \times 1,80 \mathrm{~m})$. Střední prostor je uzavřen menší obdélnou místností (o rozměrech $2,50 \times 1,50 \mathrm{~m}$ ). Směrem od středu je spojovací trakt s dvojím zalomením stěny (o rozměrech $4,00 \times 1,20 \mathrm{~m}$ ), z něhož vychází nedokončená chodbička, bez udání rozměrů a délky. Dále od ní vpravo (v délce 7,80×1,20 m) je chodba zakončená přibližně čtvercovým prostorem $(3,50 \times 3,10 \mathrm{~m})$, kterým celý sklepní prostor končí. Výška jednotlivých prostor nepřekročila $2 \mathrm{~m}$. Celý komplex byl při pokračujících stavebních pracích novostavby pohostinství postupně (v letech 1964-1965) zničen, klenby se propadly a objekt sklepů byl zcela zasypán.

V době zaměření tohoto komplexu (1963) byl prostor sklepů vyklizen. Dle sdělení místních obyvatel byl původně používán zdejším JZD na ukládání brambor. Celá stavba sklepa měla nízké, valené segmentové klenby vytvořené z cihel, zatímco obvodové zdi byly kamenné, převážně z lomového kamene, z místní žuly - granodioritu, s drobnými cihelnými vysprávkami. Zdivo bylo vybíleno vápnem $\mathrm{s}$ mnoha vrstvami vápenných omítek. Nebyly zjištěny žádné kamenné články nebo zbytky ostění. Oba vstupy do sklepů byly v době archeologického výzkumu volně př́istupné z terénu děkanského dvora.

Sklepní komplex byl součástí děkanského dvorce a nebyl nikdy spojen komunikačně se stavbou dnešní farní budovy, která nebyla podsklepena.

$\mathrm{V}$ době archeologického výzkumu byla provedena nivelace stavby. Dno sklepa na západní straně dosahovalo 458,66 m n. m. a spodní část klenby u vstupu 462,20 m n. m. Výškový rozdíl byl tedy $3,54 \mathrm{~m}$. Sklep byl vyhlouben ve sterilním podloží, které bylo $\mathrm{v}$ této části dvorce tvořeno homogenním rezavě hnědým, jílovitě hlinitopísčitým materiálem. V prostoru před západním 


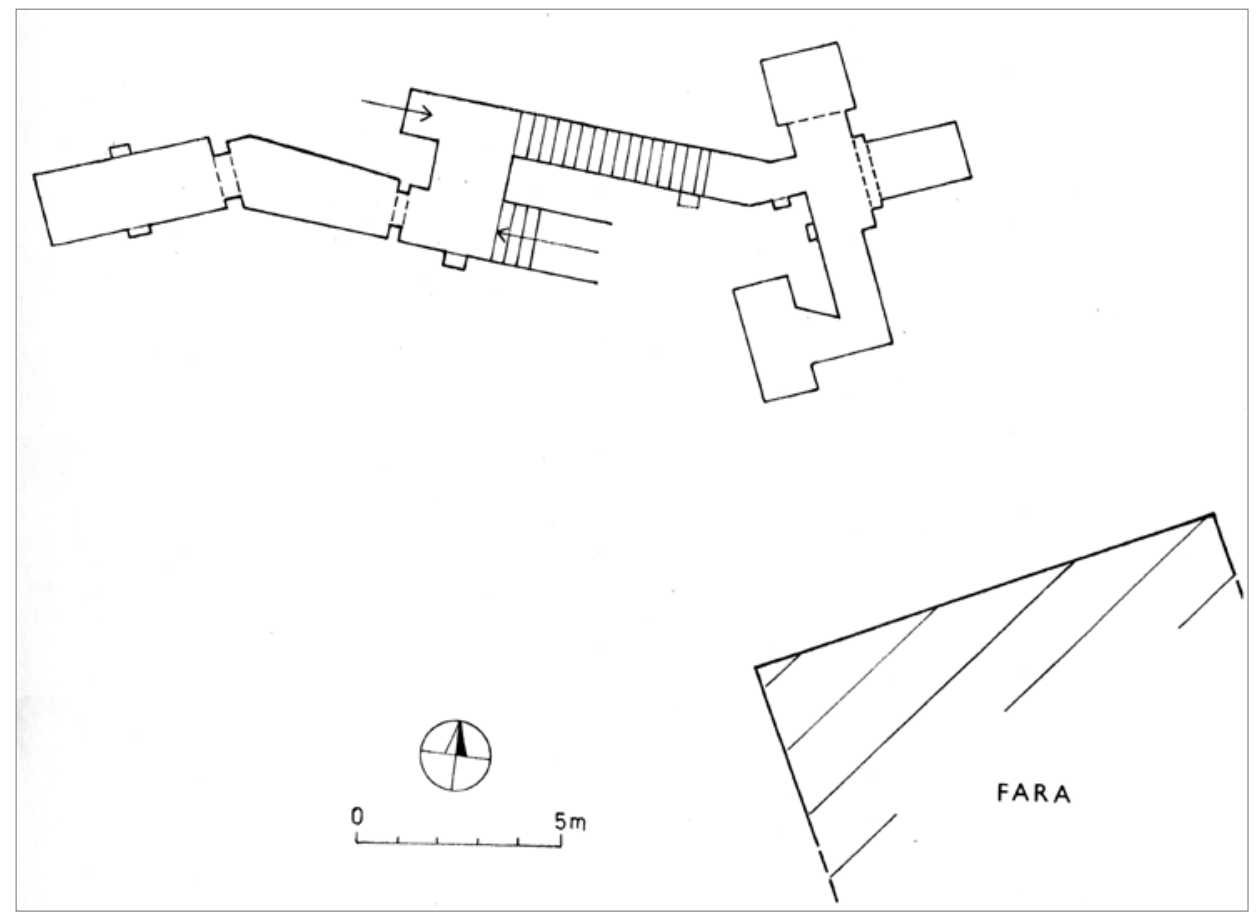

Obr. 19. Komplex renesančních sklepů v oblasti děkanského dvora v jeho východní části. Zaměření E. Pochitonov.

Abb. 19. Renaissancezeitlicher Kellerkomplex im Bereich des östlichen Teils des Dekanatshofes. Vermessung E. Pochitonov.

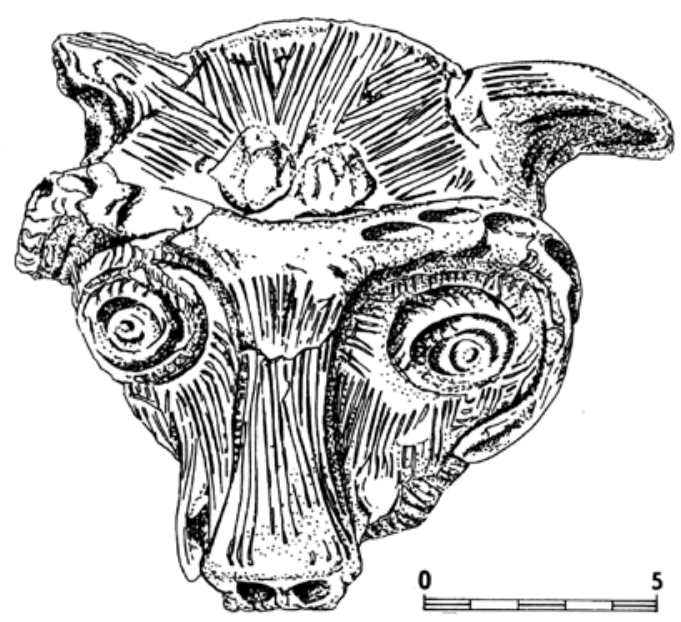

Obr. 20. Keramické středověké aquamanile nalezené v zásypu objektu O-1 (johanitské kurii). Kresba K. Kábrtová.

Abb. 20. In der Verfüllung von Objekt O-1 (johannitische Kurie) entdecktes mittelalterliches Aquamanile aus Keramik. Zeichnung K. Kábrtová. 


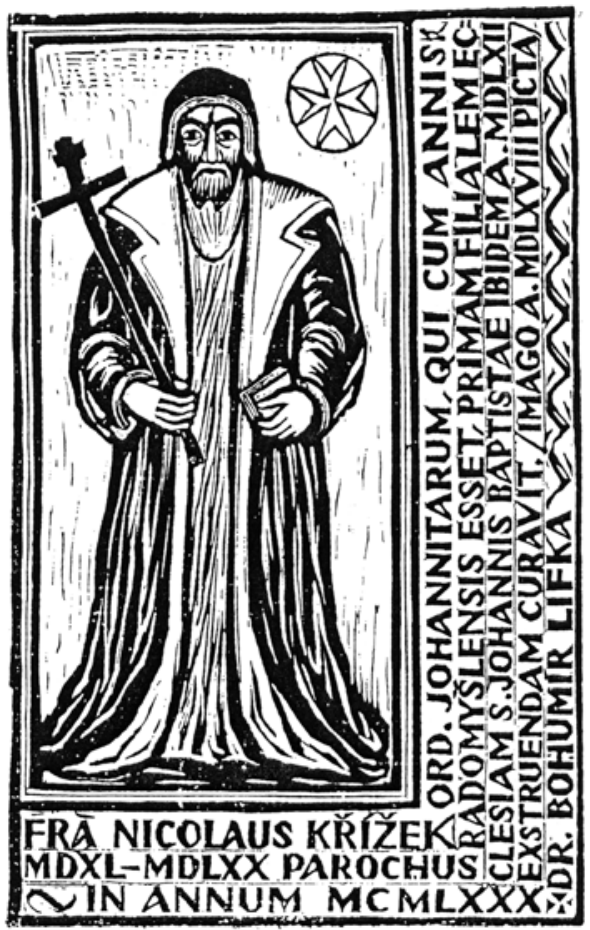

Obr. 21. Frà Mikuláš Křížek, správce fary v letech 15401570. Podle obrazu z roku 1568 použitého B. Lifkou jako inspirace pro jeho novoročenku.

Abb. 21. Frater Nikolaus Kř́ižek, Verwalter der Pfarrei in den Jahren 1540-1570. Nach einem von B. Lifka für eine Neujahrsgrußkarte als Inspirationsvorlage benutztes Bild aus dem Jahr 1568. průčelím dnešního děkanství vystupuje mělce pod humusovitým terénem skalní podloží, tvořené velmi tvrdou (na opracování) žulou granodioritem (Nechvátal 1999, 31, obr. 12; 52, obr. 37, profil 21 u sektoru S-21/68). Stejná situace byla u barokního špýchárku původně tř́iprostorové johanitské kurie (Nechvátal 1999, 47, sonda S-L 1964). V těchto místech, stejně jako v místech farního děkanství, nebylo možno sklepy vyhloubit. Skalní podloží, které bylo na obou místech, to po stavební stránce znemožňovalo. Současně to svědčí o geologických znalostech stavebníků.

Pro datování sklepního komplexu nemáme žádné stratigrafické pozorování a zjištění. Dủležitým historickým pramenem pro chronologické zařazení sklepního komplexu je vizitační protokol z let 1609-1613, tedy již z novověku, zachycující situaci v období renesance. Tehdy byla podniknuta vizitace na johanitském (maltézském) církevním panství, kam Radomyšl patřila. Rádová vizitace byla nařízena velkopřevorem Matoušem Děpoldem z Lobkovic. Provedli ji Jiří Čejka a Ladislav Žejdlic za spolupráce místních řádových veličin (Lifka 1993, 132-133). Popisy ve vizitačním protokolu, zpracované pro Radomyšl $\mathrm{v}$ roce 1610 , jsou cenným dokladem pro podobu městečka v závěru působení renesanční slohové vlny před třicetiletou válkou. U kostela sv. Jana Křtitele, řádového maltézského patrona, se vizitátorům líbila jeho jedinečná poloha nad městečkem, tehdejší bílé líčené stavby byly kryté zřejmě prejzy. Stejnou pálenou krytinu měla i věž, na níž byly zavěšeny tři zvony. Uvnitř kostelíka shledali řádoví úředníci šest oltářů a kolem kostelíka čtyři menší a větší klenuté kapličky. Dále zde byly zjištěny dvě světničky pro poustevníky, jedna komora a kamenná kostnice. U kostela již tehdy existoval hřbitov, obehnaný obílenou zdí, jejíž korunu kryly také prejzy. Všechny objekty byly tehdy v dobrém stavu, protože, jak poznamenává vizitační zápis: „Mikuláš Kř́žek byl několik let před tím kostel znovu zrrídil." Při výstavbě kostela s věncem obvodových kapliček, které jsou zmiňovány ve vizitačním protokolu, opět ožily tradiční cesty poutníků ke zdejší zázračné kapličce a studánce.

Podle vizitačního protokolu z roku 1610 se v popisu farního kostela sv. Martina v městečku dozvídáme, že raně gotická západní věž byla tehdy kryta šindelem a obsahovala tři zvony. Vlastní kostel kryla pálená krytina, stejně jako předsíň na severní straně, kterou považujeme za renesanční. Hřbitov kolem kostela obklopovala zed'. Visutá krytá lávka mezi prvním patrem sakristie a církevní kurií tříprostorového objektu, zjištěného archeologickým výzkumem, dnes v podobě barokního špýchárku, splňovala nadále svou funkci, kterou jí dalo 14. století. Stavba zanikla snad společně se středověkým jádrem církevního dvorce, zřejmě až koncem 18. století. Poslední zmínka o spojovacím můstku je z roku 1773, kdy je v kostelních účtech zpráva o pobíjení střechy šindelem (Kašička-Nechvátal 1983, 26-27; Nechvátal 1999, 185).

Z popisu vnitřního vybavení chrámu stojí za povšimnutí, vedle různého církevního bohoslužebního náčiní a rouch, připomínka čtyř oltářủ a hlavního oltáře s dřevěnou sochou Ukřižovaného. $Z$ renesančního inventáře kostela se dochovala do dnešní doby dřevěná polychromovaná 
plastika sv. Martina na koni se symbolickým žebrákem (vysoká $78 \mathrm{~cm}$ a široká $51 \mathrm{~cm}$ ), kterou pro hlavní oltář opatřil farář Mikuláš Kř́žžek. V době působení faráře Křrižka byly na kostelní věž zavěšeny dva ze tř́ zvonů, zmiňovaných vizitačním protokolem, které jsou dochovány do dnešní doby. V roce 1563 byl pro kostel ulit zvon Zikmund Tomášem Jarošem z Brna. Druhý zvon, zvaný Marie, je zdoben vlysem s legendou o marnotratném synovi a dalšími nápisovými řádky. Byl ulit na žádost Mikuláše Kř́ižka, tehdy již strakonického převora, Jakubem Volframem, kovářem z Prachatic.

Pro časové zařazení sklepního komplexu má význam druhá část vizitačního protokolu. Popis farního dvorce je významný pro představu dnes již zcela zaniklého goticko-renesančního areálu. Na faře, v místech dnešní barokní sýpky (za východním čelem kostela), připomíná vizitační protokol kamennou místnost se třemi okny, při ní probíhala malá předsíň, vzadu potom kuchyně a komora, používaná jako lázeň. Nad lázní byla dřevěná místnost s komorou. Střechu nad farou tvořila tehdy pálená krytina. $\mathrm{K}$ dalšímu př́íslušenství kurie patřila klenutá komora, stojící naproti popsanému stavení, poblíž potom dřevěná sýpka, kamenný ovčín, tř̌i kamenné chlévy pro krávy, prasata a ostatní dobytek, kamenná koňská stáj pro osm koní a konečně se uvádí - „velmi hluboký podzemni sklep“. Tento sklep musí být totožný s popisovaným sklepním komplexem, protože dnešní budova farního děkanství, vzniklá v 18. století, není podsklepena. Rovněž středověká kurie obsažená v barokním špýchárku prostorově svým malým rozsahem nevyhovuje vizitačnímu protokolu. Ani ona nemá hluboký podzemní sklep. Na základě všech těchto zjištění je nutno celek chronologicky zařadit do doby před rokem 1610, tedy před vznikem vizitačního protokolu, tj. do renesančního období. Do doby, kdy byl správcem fary (v letech 1540-1570) Mikuláš Křižek, působící zde pro 16. století neuvěřitelně dlouhou dobu, zřejmě při své mimořádně velké stavební aktivitě vybudoval i farní budovu s komplexem sklepů. Zlidovělá pověst, chtějíc vysvětlit jeho stavební aktivitu a velké náklady na ni, vypráví, že nalezl vojenskou pokladnu, na kterou ho ve snu upozornil sv. Jan Křtitel, a z ní financoval všechny své stavební počiny (Lifka 1993, 123-124).

O vlastním děkanském dvorci z archeologických výzkumů víme, že vyhořel a byl vážně poškozen patrně někdy počátkem třicetileté války a jeho sídelní budova zůstala ve zříceninách s propadlým krovem (nedoložený údaj ve Valentově kronice uvádí vyhoření staré farní budovy k roku 1621). Teprve stabilizující se situace vedla postupně k vybudování snad provizorní náhrady. Posléze bylo přistoupeno k vyzdvižení jednopatrové děkanské budovy, v odsunuté poloze vzhledem ke zbytkům stavebně starší kurie. Došlo k tomu podle písemných pramenů za faráře Petra Ostermanna v letech 1745-1747.

Výstavba nové farní budovy si patrně vynutila poničení staršího objektu - údajně z roku 1642. V době vpádu francouzsko-bavorských vojsk během války o dědictví habsburské a války o Slezsko (v roce 1742) francouzský generál starší faru obsadil a vydrancoval, současně $\mathrm{s}$ farskou sýpkou. Dnešní vnitřní uspořádání, prostor děkanství a dvojí charakter valených kleneb v př́izemí (nepodsklepené budovy) vypovídají zjevně nejméně o dvou stavebních etapách (Kašička-Nechvátal 1983, 31). Podle výsledků stavebního výzkumu je patrně starší jižní část objektu s valenými klenbami půlkruhového průřezu s trojúhelnými výsečemi. Této skutečnosti odpovídá i zřetelná spára ve zdivu na východní straně budovy, zjištěná roku 1992 při obnově fasád v jižní části.

Z jižního čela budovy (ještě v roce 1983) byly při stavebním výzkumu (Kašička-Nechvátal 1983, 31) také sejmuty všechny staré omítky - až do obnovy fasád. Byly osekány až na kámen a dosud jsou patrny před tím stopy staršího členění fasády se spodní napekovanou vápennou omítkou. Patrny byly zbytky červenavého rámování a kordonového pásu a obrys starší šambrány zazděného okna do přízemí, s hranatým uchem u dolního rohu. Zbytky červeného rámování a kordonového pásu byly také patrny na stavbě barokního špýchárku (v letech 2015-2016), obnovené $\mathrm{v}$ rámci generální opravy a rekonstrukce. Stavba trríprostorového půdorysu je jednou z mála dochovaných staveb svého druhu z doby předhusitské v českých zemích (Nechvátal 1999, 9, obr. 1). 


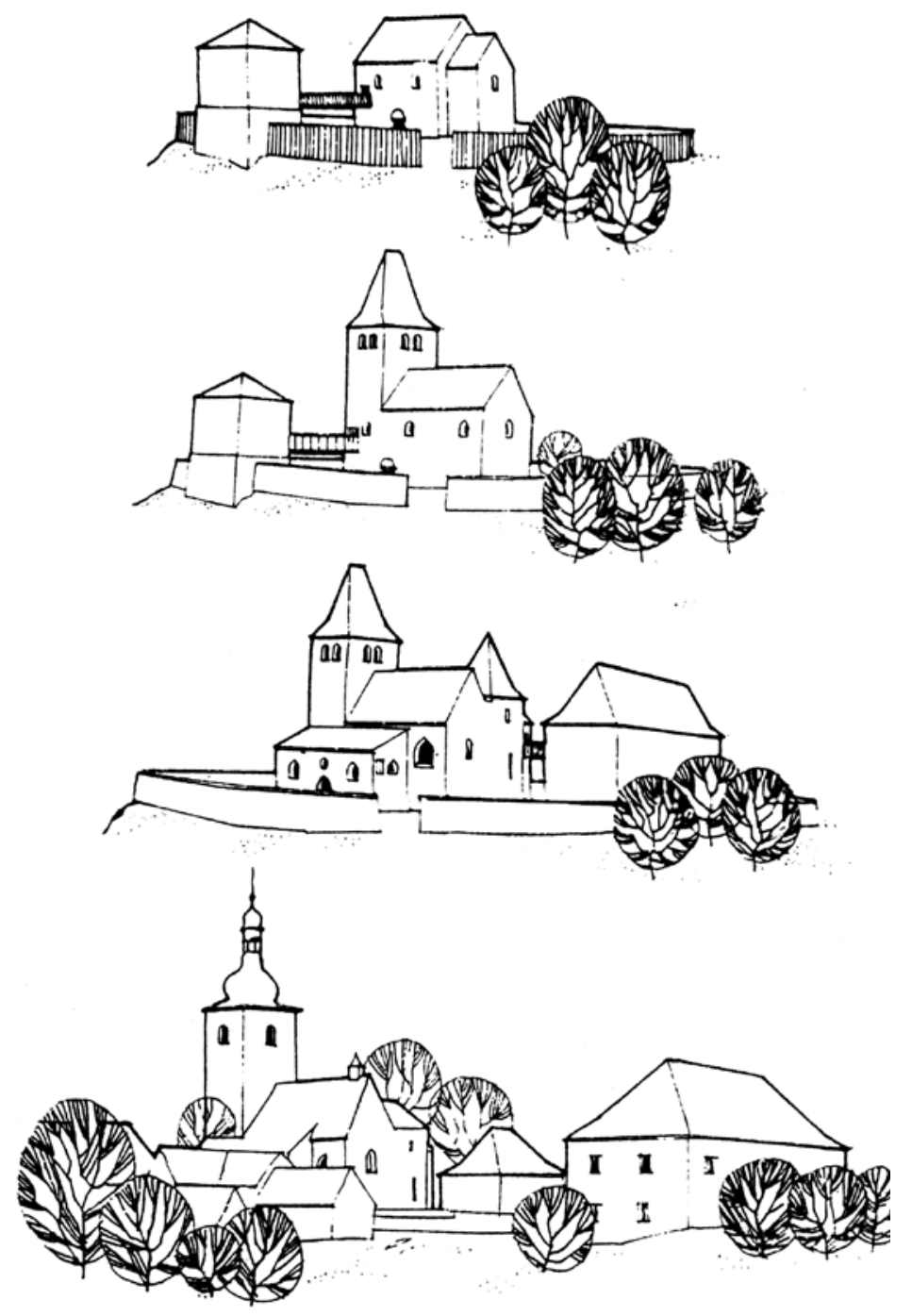

Obr. 22. Rekonstrukce kostela sv. Martina v Radomyšli s johanitskou kurií ve 12. století, v druhé polovině 13. století, koncem 14. století, dnešní stav. Na základě archeologického, historického a stavebního výzkumu provedl F. Kašička.

Abb. 22. Rekonstruktion der St. Martinskirche in Radomyšl mit johannitischer Kurie im 12. Jahrhundert, in der zweiten Hälfte des 13. Jahrhundertstoletí, Ende des 14. Jahrhunderts und dem heutigen Zustand. Von F. Kašička unter Heranziehung der archäologischen, historischen und baulichen Untersuchung angefertigt.

Hlavní podélné průčelí budovy děkanství je orientováno směrem ke kostelu východně a výtvarný důraz je kladen na členění oken prvního patra. Šambrány okenních otvorů jsou pod mohutnou fabionovou rrímsou sepnuty klenáčky a na rozích přizdobeny vztyčenými volutovými uchy, v parapetech visí (v obryse) vykrajované ploché čabraky. Příslušnost stavebníka připomíná 
(nad kamenným pravoúhlým portálem do budovy) oválný štukovaný rám s osmihrotým maltézským kř́ižem uprostřed.

IV.

To je ve stručném přehledu historie objektu a prostředí johanitského maltézského dvorce, kde byl zjištěn komplex renesančních sklepů a současné fary, jejíž počátky jsou doloženy koncem 13. století (1284), kdy je uváděna ve výčtu majetku Bavorů ze Strakonic - Radomyšl $\mathrm{s}$ farou. Fara v tomto období znamenala význačnou složku místní správní i církevní organizace (Delaville Le Roulx 1901-1905 I., 189 - ,possesiones dominorum de Straconizs... Radomisl cum parochia").

Závěrem možno shrnout hlavní etapy poznání johanitské kurie v Radomyšli u Strakonic, jejíž rozsah a objem byl dlouhodobě zvětšován v jejích jednotlivých etapách.

1. Nejstarší část byla na jižní straně románského kostela sv. Martina pocházejícího z poloviny 12. století (obr. 5). Také to dosvědčuje (obr. 4) zachovaný vstup z románské empory jižním směrem. Celková terénní situace naznačuje polohu románského šlechtického sídla, snad přímo zakladatele Radomysla, jehož sídlo mohlo sloužit i jako johanitská kurie. Stavba byla dřevěná.

2. Přesun kurie směrem východním. Stavbu označujeme jako stavební objekt O-1. Je datován do průběhu 13. století, spíše do jeho druhé poloviny. Porušuje některé $\mathrm{z}$ hrobů (hroby č. 158/63, 159/63, 196/63). Je téměř čtvercového půdorysu o rozměrech zhruba 8,90 × 8,60 m. Má dva opěrné pilíře, síla zdiva kolísá mezi $140-150 \mathrm{~cm}$. Objekt byl skryt pod úrovní dnešního terénu na straně východní a jižní 2,20-2,45 m. K jeho poškození došlo patrně koncem 13 . století nebo v prvé polovině 14 . století. Byl později přestavěn na základě vrstvy 4 , kterou tvořily cihly a dlaždice, jež se také našly v jeho interiéru (obr. 7), na zvětšený tříprostorový objekt johanitské kurie.

3. Stavba johanitské kurie $\mathrm{v}$ druhé polovině 14. století byla zcela mimořádným objektem z doby předhusitské, vzácně dochovaným v barokním plášti špýchárku. Kromě původního objektu O-1, který později zcela zanikl, je rozdělena na dvě části, severní 7,5-3,8 m a jižní 6,85-3,8 m. Stavba johanitské kurie se stala vdovským sídlem Markéty ze Šternberka, která byla vdovou po Vilému Bavorovi ze Strakonic (před rokem 1375).

4. O další etapě johanitské kurie v Radomyšli svědčí komplex sklepů v ose západ-východ přibližně $23 \times 15 \mathrm{~m}$ v severovýchodním areálu děkanského dvorce. V profilu $13 \mathrm{v}$ sektoru S-5/68 bylo zachované zdivo (obr. 18) považováno nesprávně za torzo barokní stodoly. S novým hodnocením je nutno předpokládat, že šlo původně o stavbu renesanční fary z doby rozsáhlé stavební činnosti Frà Mikuláše Křížka, který byl správcem fary v letech 1540-1570, později se stal velkopřevorem ve Strakonicích a působil v této funkci až do roku 1590.

5. Dnešní stavba děkanství je závěrečnou stavbou johanitského, respektive maltézského děkanství v Radomyšli. Hlavní podélné průčelí budovy je orientováno ke kostelu, směrem východním. Hlavní výtvarný důraz je kladen na členění oken prvního patra. Stavba budovy byla podle písemných pramenů provedena za faráře Petra Ostermanna v letech 1745-1747.

Nejlépe o jednotlivých stavbách informuje rekonstrukce kostela (obr. 22) sv. Martina v Radomyšli s johanitskou kurií ve 12. století, v druhé polovině 13. století, koncem 14. století a dnešní stav, rekonstrukci na základě archeologického, historického a stavebního výzkumu provedl F. Kašička.

Děkuji JUDr. Jiřímu Varhaníkovi za přečtení rukopisu a za cenné připomínky.

\section{Prameny a literatura}

BIBLE, 1979: Písmo svaté Starého a Nového zákona. Ekumenický překlad. Praha. 
BLAJEROVÁ, M., 1975: Kostrové pozůstatky ze slovanského pohřebiště v Radomyšli. Crania Bohémica 5. Praha.

- 1979/1999: Kostrové pohřebiště z Radomyšle (o. Strakonice) z období od středověku po novověk. In: Nechvátal, B., Radomyšl. Raně středověké pohřebiště, 252-350. Praha.

BLAJEROVÁ, M.-NECHVÁTAL, B., 2003: K demografii raně středověkých pohřebišt' v Čechách na příkladu Radomyšle u Strakonic - Zur Demographie frühmittelalterlicher Gräberfelder in Böhmen am Beispiel von Radomyšl bei Strakonice, AH 33, 399-418.

BLOCH, J.-ELIŠKA, J.-VEJVODOVÁ, L., 2015-2016: Radomyšl, farní špýchar. Operativní průzkum a dokumentace, ulož. v archivu NPÚ ÚOP v Českých Budějovicích.

CDB: Codex diplomaticus et epistolaris regni Bohemiae II. (1198-1230) (Friedrich, G., ed.). Praha 1912.

DELAVILLE LE ROULX 1901-1905: Cartulaire general del'orde de St. Jean de Jerusalem. Tome I. Paris.

FRÖHLICH, J., 1985: Středověká dlaždice ze Štítkova, okr. Strakonice, CB I, 327-330.

KAŠIČKA, F.-NECHVÁTAL, B., 1983: Radomyšl - proměny městečka. Strakonice.

KUČA, K., 2004: Města a městečka v Čechách na Moravě a ve Slezsku. Sv. VI. Praha.

LIFKA, B., 1936: Staří a noví usedlíci v Radomyšli za 350 let, Strakonicko II, 1-20.

- 1993: Radomyšl. Dějiny jihočeského městečka a jeho okolí. Z pozůstalosti vydal a obrazovou část doplnil a resume napsal Bořivoj Nechvátal. Radomyšl.

MENCL, V., 1980: Lidová architektura v Československu. Praha.

MITÁČEK, J., 2010: Byla v Brtnici komenda řádu johanitů? In: Zaměřeno na stř̌edověk. Zdeňkovi Měřínskému k 60. narozeninám (Přichystalová, R.-Ungerman, Š., edd.), 608-617. Praha.

NECHVÁTAL, B., 1980: Mladohradištní pohřebiště, sídlištní objekty a kostel v Radomyšli u Strakonic, I.-VIII. nál. zpr. čj. 5273/80, ulož. v archivu nálezových zpráv ARÚ AV ČR.

- 1997: K nálezové problematice mladohradištního pohřebiště v Radomyšli u Strakonic - Zur Problematik der Fundsituation des Gräberfeldes in Radomyšl bei Strakonice, AH 22, 61-96.

- 1999: Das frühmittelalterliche Gräberfeld in Radomyšl bei Strakonice. In: Archälogische Arbeitsgemeinschaft Ostbayern / West- und Südböhmen 8. treffen 17. bis 20. Juni in Běšiny bei Klatovy, 201-219. Rahden, Westfalen.

- 1999a: Radomyšl. Raně středověké pohřebiště. S antropologickou analýzou M. Blajerové a s příspěvky Z. Hazlbauera a J. Macharta. Praha.

- 2001: Die archälogische Erforschung der St. Martin Kirche in Radomyyšl bei Strakonice - Ergebnisse und Probleme. In: Archälogische Arbeitsgemeinschaft Ostbayern / West- und Südböhmen. 10. Treffen 7. bis 10. Juni in Český Krumlov, 188-209. Rahden, Westfalen.

- 2010: Záchranný výzkum v poloze tzv. „Tomanovny“ na raně středověkém pohřebišti v Radomyšli u Strakonic - Die Rettungsgrabung in der sog. Lage „Tomanovna“ auf dem frühmittelalterlichen Gräberfeld in Radomyšl bei Strakonice, AH 35, 121-134.

- 2013: Padesát let od objevu raně stř̌edověkého pohřebiště v Radomyšli u Strakonic, AVJČ 26, 332-341.

- v tisku: K počátkům hradu ve Strakonicích (v přípravě pro $\mathrm{AH}$ ).

NECHVÁTAL, B.-STRÁNSKÁ, P.-SVĚTLÍK, I., 2012: Radiouhlíkové datování raně středověkého pohřebiště v Radomyšli u Strakonic - Radiokohlenstoffdatierung des frühmittelalterlichen Gräberfeldes in Radomyšl bei Strakonice, AH 37, 497-505.

NĚMEC, K., 1936: Dějiny města Horažd'ovic. Horažd'ovice.

NOVOTNÝ, F., 2015: Restaurátorský průzkum omítek fasády objektu bývalé části tvrze v Radomyšli. Rkp. ulož. v archivu NPÚ ÚOP v Českých Budějovicích.

RADOMĚRSKÝ, P.-RICHTER, M., 1974: Korpus české středověké keramiky datované mincemi, SbNM A XXVIII, 57-171.

RBM: Regesta diplomatica nec non epistolaria Bohemiae et Moraviae I. (600-1253) (Emler, J., ed.); II. (1253-1330) (Emler, J., ed.).

SKOLIL, M., 1993: Založení komendy johanitů na Malé Straně. Příspěvek k otázce prŕíchodu řádu do Čech, Pražský sborník historický XXVI, 7-37.

STEHLÍKOVÁ, E., 2016: Výzkumná zpráva o dendrochronologické analýze. Radomyšl - objekt farní sýpky. Rkp. ulož. v archivu NPÚ ÚOP v Českých Budějovicích.

STRÁNSKÁ, P., 2010: Antropologická charakteristika kostrových pozůstatků z raně středověkého pohřebiště v Radomyšli, okr. Strakonice (poloha „Tomanovna“) - Eine anthropologische Charakteristik der 
Skelettüberreste vom frühmittelalterlichen Gräberfeld in Radomyšl, Bez. Strakonice (Lage „Tomanovna“), AH 35, 135-140.

VLČEK, P.-SOMMER, P.-FOLTÝN, D., 1997: Encyklopedie českých klášterů. Praha.

\section{Zusammenfassung}

\section{Zur johannitischen Kurie in Radomyšl bei Strakonice}

Bei der in den Jahren 1963-1968 vom Archäologischen Institut der Tschechischen Akademie der Wissenschaften auf einem frühmittelalterlichen jungburgwallzeitlichen Gräberfeld zunächst als Rettungsgrabung und später systematisch durchgeführten Grabung fand man außer 1000 bis 1200 Bestatteten eine Reihe von mittelalterlichen Objekten. Außer der Untersuchung der romanischen Kirche aus der Mitte des 12. Jahrhunderts entdeckte man auch eine johannitische Kurie in der Hülle eines barocken Getreidespeichers und einen ausgedehnten Kellerkomplex (Nechvátal 1999; 2008). In den Jahren 2015-2016 wurde eine Generalsanierung und bauliche Sicherung der johannitischen Kurie durchgeführt. Die bauliche Untersuchung und Vermessung des Baus wurde von den Mitarbeitern der Arbeitsstelle des Nationalen Denkmalinstituts in České Budějovice durchgeführt (Jiří Hloch, Jan Eliška, Lenka Vejvodová), die archäologische erfolgte unter der Leitung von Vlastimil Král vom Museum des mittleren Otavagebietes in Strakonice. Die Revision der alten Dokumentation und ihre kritische Beurteilung führten unter Heranziehung der neuen Feststellungen zu einer Präzisierung der Erkenntnisse.

Die historischen Hauptetappen der johannitischen Kurie, deren Ausdehnung und Umfang im Laufe der Zeit vergrößert wurde, kann folgendermaßen zusammengefasst werden.

1. Der älteste Teil befand sich an der Südseite der aus der Mitte des 12. Jahrhunderts stammenden St. Martinskirche (Abb. 5). Darauf deutet auch der erhaltene Eingang von der romanischen Empore in südlicher Richtung hin (Abb. 4). Die gesamte Geländesituation deutet die Lage eines romanischen Adelssitzes an, bei dem es sich wahrscheinlich um den Sitz des Gründers von Radomysl gehandelt hat, der auch als johannitische Kurie gedient haben konnte. Es handelte sich ursprünglich um einen Holzbau.

2. In der weiteren Etappe wird die Kurie nach Osten verlagert. Sie wird als Bauobjekt O-1 bezeichnet und ins 13. Jahrhundert datiert, eher in dessen zweite Hälfte. Das Objekt stört einige der Gräber. Sein Grundriss ist fast quadratisch und hat die Abmessungen 8,90 × 8,60 m sowie zwei Stützpfeiler. Die Stärke des Mauerwerks schwankt zwischen 140-150 cm. Das Objekt war in einer Tiefe von 2,20-2,45 m unter dem heutigen Geländeniveau verborgen. Zu seiner Beschädigung war es offenbar Ende des 13. oder in der ersten Hälfte des 14. Jahrhunderts gekommen. Später wurde es auf dem Untergrund von Schicht 4, die den gleichen Höhenverlauf hat wie der nördliche und südliche Raum (vgl. Abb. 7), zu dem dreiräumigen Objekt der johannitischen Kurie vergrößert. Schicht 4 bestand aus Ziegel- und Pflastersteinen, die auch in seinem Innenraum gefunden wurden.

3. Der Bau der johannitischen Kurie in der zweiten Hälfte des 14. Jahrhunders war ein ganz außergewöhnliches, nicht alltäglich in der barocken Hülle eines Getreidespeichers erhalten gebliebenes Objekt aus vorhussitischer Zeit. Abgesehen von dem ursprünglichen, später völlig verschwundenen Objekt $\mathrm{O}-1$, ist es in zwei Teile untergliedert, in einen nördlichen $(7,5-3,8 \mathrm{~m})$ und einen südlichen $(6,8-3,8 \mathrm{~m})$. Es wurde zum Witwensitz von Margarethe von Sternberg, der Witwe von Wilhelm Bavor von Strakonitz (vor 1375). Das Objekt war wahrscheinlich in einen weltlichen und einen kirchlichen Teil unterteilt.

4. Von der weiteren Etappe zeugt der Kellerkomplex in der W-O-Achse mit den Abmessungen von ungefähr $23 \times 15 \mathrm{~m}$ im nordöstlichen Teil des Dekanatshofes. Im Profil 13/68 in Sektor S-5/68 blieb ein Mauerwerk erhalten (Abb. 18), das fälschlicherweise als Torso einer barocken Scheune angesehen wurde. Aufgrund einer Neubeurteilung muss angenommen werden, dass es sich dabei ursprünglich um den Bau des renaissancezeitlichen Pfarrhauses aus der 
Zeit der umfangreichen Bautätigkeiten von Frater Nikolaus Křížek handelt, der in den Jahren 1540-1570 Verwalter der Pfarrei war. Später wurde er Großprior in Strakonice und bekleidete dieses Amt bis zum Jahr 1590. Der Kellerkomplex wird in der Beschreibung der Visitation aus dem Jahr 1610 am besten beschrieben. Die Kurie in dem barocken Getreidespeicher ist auch im heutigen Dekanat nicht unterkellert. Im Visitationsprotokoll ist die Rede von einem sehr tiefen Keller. Die Fundamente des Baus wurden noch vor Beginn der archäologischen Grabung ausgebaggert, sodass die Struktur des Grundrisses nicht ermessen werden kann.

5. Das heutige Dekanatsgebäude stellt in der Entwicklung der Kurie von Radomyšl den abschließenden Bau dar. Die Hauptlängsfront des Gebäudes ist zur Kirche hin nach Osten ausgerichtet. Der gestalterische Akzent wurde auf die Gliederung der Fenster des ersten Stockwerks gelegt. Der Bau wurde laut den schriftlichen Quellen unter Pfarrer Peter Ostermann in den Jahren 1745-1747 durchgeführt.

Die einzelnen Etappen werden anhand der Rekonstruktion der St. Martinskirche in Radomyšl aufgezeigt (vgl. Abb. 22), anhand welcher die johannitische Kurie im 12. Jahrhundert, in der zweiten Hälfte des 13. Jahrhunderts, Ende des 14. Jahrhunderts und der heutige Zustand dargestellt werden (nach F. Kašička).

Ich danke Herrn JUDr. Jiří Varhaník für die Durchsicht des Manuskripts und seine wertvollen Anmerkungen.

PhDr. Bořivoj Nechvátal, CSc., Archeologický ústav AV ČR, Praha, v. v. i., Výzkum Vyšehrad, Štulcova 4, 12000 Praha, Česká republika, tel.: 224918 758,nechvatal@arup.cas.cz 
